2-14-2003

\title{
Examination of The Role of The Clamp-loader and ATP Hydrolysis in The Formation of The Bacteriophage T4 Polymerase Holoenzyme
}

\author{
Michael A. Trakselis \\ Pennsylvania State University \\ Anthony J. Berdis \\ Cleveland State University, A.BERDIS@csuohio.edu \\ Stephen J. Benkovic \\ Pennsylvania State University
}

Follow this and additional works at: https://engagedscholarship.csuohio.edu/scichem_facpub

Part of the Biochemistry Commons, and the Chemistry Commons

How does access to this work benefit you? Let us know!

\section{Recommended Citation}

Trakselis, Michael A.; Berdis, Anthony J.; and Benkovic, Stephen J., "Examination of The Role of The Clamp-loader and ATP Hydrolysis in The Formation of The Bacteriophage T4 Polymerase Holoenzyme" (2003). Chemistry Faculty Publications. 192.

https://engagedscholarship.csuohio.edu/scichem_facpub/192

This Article is brought to you for free and open access by the Chemistry Department at EngagedScholarship@CSU. It has been accepted for inclusion in Chemistry Faculty Publications by an authorized administrator of EngagedScholarship@CSU. For more information, please contact library.es@csuohio.edu. 


\title{
Examination of the Role of the Clamp-loader and ATP Hydrolysis in the Formation of the Bacteriophage T4 Polymerase Holoenzyme
}

\author{
Michael A. Trakselis, Anthony J. Berdis and Stephen J. Benkovic
}

\section{Introduction}

The coordinated efforts of many proteins are responsible for processive DNA replication in organisms ranging from bacteriophages to eukaryotes. Many of these individual proteins share structural homology throughout different species, although subtle differences in the mechanisms of holoenzyme assembly and replication make each system unique. In bacteriophage $\mathrm{T} 4$, the replicative holoenzyme is composed of the DNA polymerase (gp43), the processivity factor (gp45), and the clamp-loading protein (a 4:1 complex of gp44 and gp62, respectively). ${ }^{1,2}$ The polymerase holoenzyme is a highly processive system due to the topological link that the clamp, gp45, provides between the DNA and the polymerase, gp43. ${ }^{3}$ Gp45 is a ringshaped trimeric protein, which shares very similar structural properties to the $\beta$ clamp from E. coli as well as PCNA from eukaryotes. ${ }^{4}$ Detailed kinetic experiments using stopped-flow fluorescence resonance energy transfer (FRET) have resulted in structural models for gp45 that arise during the distinct steps leading to holoenzyme assembly. ${ }^{5,6}$

The clamp-loader complexes: gp44/62 from bacteriophage T4, $\gamma$ complex from E. coli, and RF-C complex from eukaryotes are all multiprotein complexes that hydrolyze ATP in formation of the holoenzyme. The role of the clamp-loader is to load the clamp onto DNA and facilitate its interaction with the polymerase. Recent high and low resolution structures of the clamp-loaders from 
E. coli, ${ }^{7,8}$ P. furious, ${ }^{9,10}$ and humans ${ }^{11}$ have provided structural mechanistic models for loading the clamp onto DNA. ${ }^{12}$ Gp44/62 is thought to dissociate from the holoenzyme after the latter's formation, ${ }^{13}$ the $\gamma$ complex dissociates from the $\beta$ clamp after loading, but remains associated with the $\tau$ subunit of DNA polymerase III, ${ }^{14,15}$ and like gp44/62, the RF-C complex is thought to dissociate from PCNA after loading the clamp. ${ }^{16}$ In all systems, ATP hydrolysis by the clamp-loader occurs during the reaction cycle either in the loading of the clamp onto DNA, in its subsequent interaction with the polymerase to form the holoenzyme, or in dissociation of the clamp-loader.

The specific number of molecules of ATP and the step in which ATP is hydrolyzed seems to vary in each system. In the E. coli replication system, two to three molecules of ATP are hydrolyzed by the $\gamma$ complex upon interaction with DNA ${ }^{17-19}$ although ATP hydrolysis apparently is not coupled to clamp opening but to closing. ${ }^{20}$ In the eukaryotic system, four molecules of ATP are bound to the RF-C complex sequentially: two molecules before and two molecules after addition of $\mathrm{DNA}^{21,22}$ although only three molecules of ATP are necessary for eukaryotic clamp loading. ${ }^{23}$ Though hydrolysis of ATP is necessary for effective loading of PCNA onto DNA by the RF-C complex, ATP $y$ S also promotes loading of PCNA onto DNA but leads to an inactive form. ${ }^{24-27}$ This suggests that the binding of ATP to the RF-C complex of the eukaryotic system may be sufficient to load PCNA onto DNA, and ATP hydrolysis may only be important in subsequent events including clamp closing and complexation with the polymerase.

In the bacteriophage T4 DNA polymerase holoenzyme, it had been reported by our laboratory as well as others that gp44/62 binds four molecules of ATP, and hydrolysis of ATP was necessary for formation of the holoenzyme. ${ }^{13,28,29}$ Hydrolysis of ATP was described to proceed sequentially with two molecules hydrolyzed to open gp45 and an additional two molecules hydrolyzed to close the clamp onto DNA. ${ }^{5,6,30-33}$ New evidence from a variety of rapid-quench experiments disputed the occurrence of the previously identified ATP hydrolysis steps and concluded that only one molecule of ATP is hydrolyzed after addition of DNA to the holoenzyme. ${ }^{34}$ We were therefore compelled to reinvestigate the role of gp44/62 in bacteriophage T4 holoenzyme assembly and broaden our inquiry to define more exactly all steps in which the clamp-loader participates.

Here, we investigated the opening of gp45 in the presence of various nucleotides by measuring the magnitude of the opening of the subunit interface of gp45 upon interaction with gp44/62 using intramolecular FRET. We found that ATP hydrolysis apparently was necessary to open the clamp wide enough so that it could be loaded onto dsDNA. We also used interprotein FRET to detail the chaperone-like role of gp44/62 in formation of the holoenzyme. Gp44/62 mediates the interaction between gp45, DNA, and gp43. We observed transient formation of a multiprotein complex, gp45.gp44/62.DNA.gp43, that upon release of gp44/62 forms the active holoenzyme composed solely of gp45.DNA.gp43. Once again, we used rapid-quench techniques to detail the ATP hydrolysis events during holoenzyme formation and extended our study to include the effects of differences in quenching techniques. Holoenzyme formation was reconfirmed to occur through the sequential hydrolysis of two molecules of ATP before and after addition of DNA consistent with previous results from our lab as well as others but inconsistent with the recent report. ${ }^{34}$ The discrepancy between the two studies was traced to the quenching procedure used. We extended our inquiry to include pulse-chase experiments that suggested in the absence of DNA two equivalents of bound ATP rapidly dissociate to free ATP and no significant partitioning of gp45.gp44/62.ADP.P $P_{i}$ complex to free ATP occurs. In brief, there is a high commitment to catalysis. The collective data, thus, identifies the overall role of gp44/62 during bacteriophage T4 holoenzyme formation as a clamp-loader fueled by ATP hydrolysis and a chaperone facilitating the interaction between gp45 and gp43.

\section{Results}

\section{Only a hydrolysable form of ATP opens the clamp in the presence of the clamp-loader}

\section{Intraprotein stopped-flow FRET}

Using presteady-state stopped-flow fluorescence, it is possible to measure rates of fluorescent changes contributing to different spatial and functional states of proteins. In this particular case, a mutant of gp45 (W199F/V163C or W199F/ $\mathrm{V} 163 \mathrm{C} / \mathrm{W} 92 \mathrm{~F}$ ) was used to quantitate distances between an inherent tryptophan donor (W92) in the subunit interface of gp45 and a coumarin (CPM) acceptor attached to a mutated cysteine (V163C) on the other side of the subunit interface. ${ }^{5,6}$ This site-specific donor/acceptor pair allows for observed changes in FRET to be transformed into changes in distance between the pair. With this method, it was possible to follow alterations in gp45 subunit interfacial distances upon interaction with gp44/62 and ATP. Previous measurements had shown that a fluorescence change associated with clamp opening was absent when ADP or ATP $\gamma \mathrm{S}$ was used in place of ATP. ${ }^{5}$ Although this suggested that a hydrolysable form of ATP is necessary for further opening of gp45 in the presence of gp44/62, the separation of the donor acceptor pair had not been measured.

Expanding on this study, it was possible to measure the change in distance across the subunit interface of gp45 complexed to gp44/62 in response to various ATP analogs. Changes in 
Table 1. Experimental intraprotein FRET distances between W92 and V163C-CPM of gp45

\begin{tabular}{|c|c|c|c|c|}
\hline $\mathrm{Gp} 45^{\mathrm{a}}$ state & $\begin{array}{c}\text { No analog } \\
(>\AA)\end{array}$ & $\begin{array}{c}\mathrm{ADP} \\
(\AA)\end{array}$ & $\underset{(\AA)}{\operatorname{ATP} \gamma S}$ & $\begin{array}{c}\text { ATP } \\
(\AA)\end{array}$ \\
\hline A & $40.0^{\mathbf{b}}$ & $40.0^{\mathrm{b}}$ & $40.0^{\mathrm{b}}$ & $40.0^{\mathrm{b}}$ \\
\hline B & $40.0^{\mathrm{b}}$ & $40.0^{\mathrm{b}}$ & $40.0^{\mathrm{b}}$ & $40.0^{\mathrm{b}}$ \\
\hline C & $38.5^{\mathbf{b}}$ & 38.3 & 37.2 & $40.7^{\mathbf{b}}$ \\
\hline D & $\mathrm{N} / \mathrm{A}^{\mathrm{c}}$ & $\mathrm{N} / \mathrm{A}^{\mathrm{c}}$ & $\mathrm{N} / \mathrm{A}^{\mathrm{c}}$ & $>45^{\mathrm{b}}$ \\
\hline
\end{tabular}

Stopped flow fluorescence experiments were performed and observed experimental values were converted to distances as described in Materials and Methods. Final concentrations were $1 \mu \mathrm{M}$ gp44/62, $1 \mu \mathrm{M}$ gp45/V163C/W199F CPM, and $2 \mathrm{mM}$ ATP analog. Errors in distance measurements are typically $10 \%$ of the value.

a Gp45 states are described in Figure 9.

b Experimental values were determined previously. ${ }^{5}$

c No fluorescence change associated with conversion to state D without a hydrolysable form of ATP.

FRET associated with clamp opening for the clamp protein, W199F/V163C-CPM, in the presence of gp44/62 were obtained at $290 \mathrm{~nm}$ excitation for various ATP analogues using methods described previously. ${ }^{5}$ In order to correct for FRET associated with environmental changes or interprotein association, a triple mutant, gp45-W199F/V163C/W92FCPM was constructed and examined under the same stopped flow FRET conditions as W199F/ V163C-CPM.

Syringe A, containing $2 \mu \mathrm{M}$ gp45-W199F/ V163C/W92F-CPM in assay buffer and syringe B, containing $2 \mu \mathrm{M}$ gp44/62 with $2 \mathrm{mM}$ ADP or ATP $y$ S were mixed in the stopped-flow reaction analyzer in fluorescence mode. The excitation wavelength was set at either $290 \mathrm{~nm}$ or $390 \mathrm{~nm}$ and fluorescence emission was observed above $420 \mathrm{~nm}$ using a cut-off filter. Mixing of the syringes diluted the reaction to $1 \mu \mathrm{M}$ final concentration. Single normalized fluorescent amplitude increases $\left(F_{\mathrm{A}}^{290}\right.$ and $\left.F_{\mathrm{A}}^{390}\right)$ with inclusion of ADP or ATP $\gamma \mathrm{S}$ were recorded and listed in Table S1, Supplementary Material. FRET changes observed with gp45V163C/W199F-CPM $\left(F_{\mathrm{AD}}^{290}\right)$ were measured as done previously. ${ }^{5}$ These three parameters $\left(F_{\mathrm{AD}}^{290}, F_{\mathrm{A}}^{290}\right.$, and $F_{\mathrm{A}}^{390}$ ) are sufficient to provide values for $I_{\mathrm{AD}} / I_{\mathrm{A}}$ in order to calculate distances between the donor tryptophan (W92) and the acceptor CPM as gp45 is converted from state $\mathrm{B}$ to state $\mathrm{D}$ (Table 1 and Figure 9) based on the previously determined $R_{0}$ value of $31 \AA .{ }^{33}$

In the absence of a hydrolysable form of ATP, gp44/62 does not open gp45 to the extent necessary for its facile loading onto DNA (Table 1). Inclusion of either ADP or ATP $\gamma$ S in the stoppedflow FRET experiment only produces a single exponential change in FRET. This single exponential change in FRET probably corresponds to conformational changes between gp45 and gp 44/62 without hydrolysis of ATP to open gp45. When ATP was used in this experiment, a double exponential change in FRET was observed, suggesting an additional step leading to state $\mathrm{D}$ beyond the first conformational change (state C). ${ }^{5}$ This additional step also increased the distance between the tryptophan and CPM in the subunit interface of gp45 from $\sim 40 \AA$ to $>45 \AA$ (Table 1). Therefore, only the inclusion and hydrolysis of ATP led to gp45 loading onto DNA through step 3.

\section{Gp44/62 leaves after formation of the T4 polymerase holoenzyme}

\section{Steady-state fluorescence and activity properties of gp43-4FW}

Creation of a gp43 devoid of tryptophans was necessary to study the molecular interactions between the donor tryptophans from gp44/62 and a CPM-labeled gp45 mutant. Non-fluorescent 4fluorotryptophan (4FW) was incorporated in vivo into gp43 replacing the native tryptophan residues to create a DNA polymerase holoenzyme system whose only tryptophan residues belonged to gp44/62. Residual fluorescence was observed for gp43-4FW but was decreased to approximately $25 \%$ that of gp 43 at identical protein concentrations of $200 \mathrm{nM}$ (Supplemental Material Figure S1). This background fluorescence is likely due to tyrosine fluorescence and/or retention of one or more of the 12 native tryptophan residues. Therefore, the minimum yield of $4 \mathrm{FW}$ incorporation in the gp43$4 \mathrm{FW}$ protein preparation is estimated to be $75 \%$. The ability of gp43-4FW to slow ATP hydrolysis by gp44/62 in the presence of gp45 was verified through a coupled spectrophometric assay and is in accord with holoenzyme formation. ${ }^{30} \mathrm{Gp} 45$ weakly stimulates ATP hydrolysis by gp44/62 (basal rate of $\sim 30 \mathrm{nM} \mathrm{s}^{1}$ ). Upon addition of DNA, ATP hydrolysis is strongly stimulated $\left(\sim 300 \mathrm{nM} \mathrm{s}^{1}\right)$. Addition of gp43 decreases the ATP hydrolysis rate $\left(\sim 45 \mathrm{nM} \mathrm{s}^{1}\right)$, presumably by sequestering the holoenzyme complex onto DNA. Addition of gp43-4FW to the gp44/62.gp45.DNA complex reduces the ATP hydrolysis rate to $52 \mathrm{nM} \mathrm{s}^{1}$, similar to the rate found with native gp43.

The strand displacement assay monitors processive DNA synthesis on the Bio62/34/36mer substrate by testing the ability of the holoenzyme to extend a DNA primer and displace the single strand 36mer. ${ }^{13,33}$ Extension of a $5^{\prime}\left[{ }^{32} \mathrm{P}\right]$ labeled 34 mer oligonucleotide results in full length $62 \mathrm{mer}$ $\left[{ }^{32} \mathrm{P}\right]$ labeled products. Polymerase that is released from the DNA either by completing synthesis or through dissociation can be trapped in solution by salmon sperm DNA and will not participate in further DNA synthesis. The ratio of strand-displaced full length products to unextended 34mer was used to compare one kinetic property of the two polymerases. Compared to gp43, gp43-4FW displays near wild-type activity with only a $15 \%$ decrease in rate of full length DNA products synthesized (data not shown). 


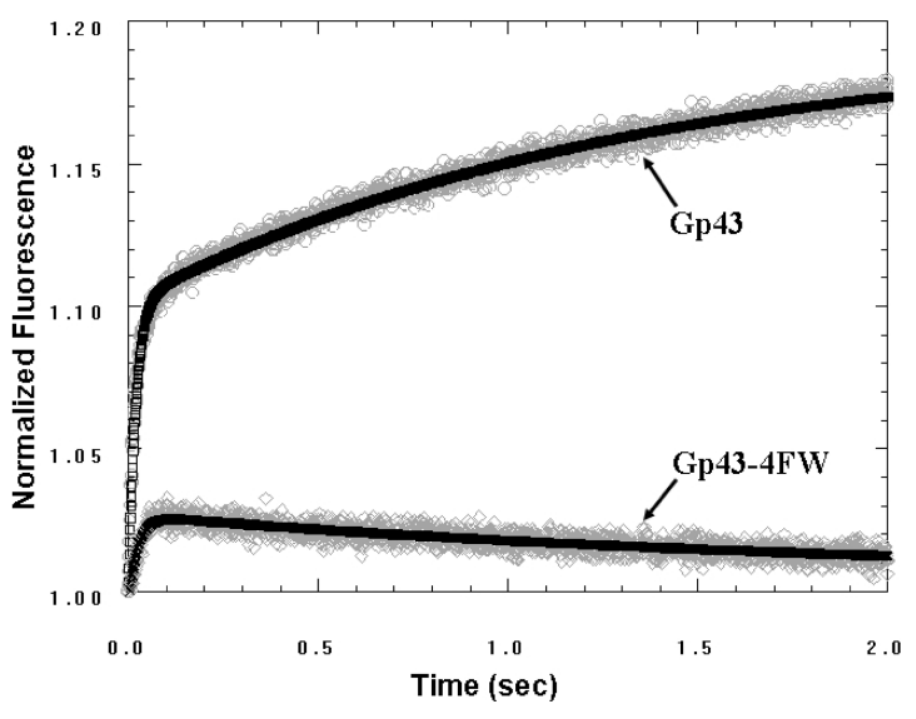

state of gp44/62.gp45.DNA.gp43. The opposite fluorescent change between the two cases in the second exponential is a result of the dissociation of gp $44 / 62$ to form the functional holoenzyme, gp $45^{\mathrm{K}} \cdot \mathrm{DNA} \cdot \mathrm{gp} 43$.

\section{Interprotein stopped-flow FRET}

Direct measurement of the protein-protein interactions between gp45 and gp44/62 in the presence of gp43 was measured using stopped-flow FRET. A CPM-labeled mutant of gp45 (W199F/S158C/ W92F) was shown previously to exhibit a high degree of interprotein FRET between its CPM label and the tryptophans in gp44/62, owing to their close proximity. ${ }^{6}$ The following stopped-flow FRET experiment was performed essentially as above and now monitors the loss of the FRET signal between gp45-W199F/S158C/W92F-CPM and gp44/62 due to dissociation of gp44/62 from the holoenzyme. In order to control for the interprotein and intraprotein contributions to FRET arising from (1) gp43, the wild-type enzyme was replaced by gp43-4FW and (2) gp45, the tryptophans in wild-type clamp protein were substituted with phenylalanine. Syringe A, containing $1 \mu \mathrm{M}$ of gp45-W199F/S158C/W92F-CPM, gp44/62, and DNA in assay buffer with $2 \mathrm{mM}$ ATP, was mixed with syringe $B$, containing either $1 \mu \mathrm{M}$ gp43 or $1 \mu \mathrm{M}$ gp43-4FW, and the change in FRET was monitored. In the first case when gp45-W199F/S158C/ W92F-CPM, gp44/62, and DNA were mixed with gp43, two increases in fluorescence were seen with observed rates of $48 \pm 6 \mathrm{~s}^{1}$ and $0.65 \pm 0.09 \mathrm{~s}^{1}$ and normalized fluorescence values $\left(F_{\mathrm{AD}}^{290}\right)$ of $1.112 \pm 0.003$ and $1.197 \pm 0.005$ (Figure 1). In the second case when gp45-W199F/S158C/W92FCPM, gp44/62, and DNA were mixed with gp43$4 \mathrm{FW}$, an increase followed by a decrease in fluorescence was seen with observed rates of $55 \pm 8 \mathrm{~s}^{1}$ and $0.54 \pm 0.08 \mathrm{~s}^{1}$ and normalized fluorescence values $\left(F_{\mathrm{AD}}^{290}\right)$ of $1.026 \pm 0.002$ and $1.009 \pm 0.004$ (Figure 1). The ratio of the first normalized change in fluorescence between gp43-4FW and gp43 is $23 \%$ corresponding to the estimated amount of native tryptophan retained in $43-4 \mathrm{FW}$ measured above. The second opposing fluorescent change
Figure 1. Normalized stoppedflow fluorescence traces for preassembled gp45, gp44/62, and DNA versus gp43 or gp43-4FW. Each trace is an average of at least five experiments done twice. Final concentrations were $0.5 \mu \mathrm{M}$ gp 44/62, $0.5 \mu \mathrm{M}$ gp $45,0.5 \mu \mathrm{M}$ Bio62/34/ 36mer, $0.5 \mu \mathrm{M}$ streptavidin, and $0.5 \mu \mathrm{M} \quad$ gp43 or gp43-4FW. Although each fluorescence trace was fit to a double exponential with rates of $48 \pm 6 \mathrm{~s}^{1}$ and $0.65 \pm 0.09 \mathrm{~s}^{1}$ for gp43 and $55 \pm 8 \mathrm{~s}^{1}$ and $0.54 \pm 0.08 \mathrm{~s}^{1}$ for gp43-4FW and represent steps 9 and 10 in Figure 9(c), the direction of the second fluorescent change is opposite between the two cases. In both cases, the first exponential change leads to a "chaperone-like" between the two cases represents a residual difference in the total interprotein FRET arising from the labeled gp45 versus gp43 or gp43-4FW.

The first observed rates in the positive direction correspond to a conformational change within the gp45.gp44/62.DNA.gp43 complex, step 9 Figure 9. The second opposing fluorescent change measures the same kinetic assembly step shown in Figure 9, step 10 , but by using gp43-4FW, we can now assign this step to the departure of gp44/62. If gp44/62 stayed associated with the holoenzyme at state $\mathrm{K}$, then the residual fluorescence from gp43-4FW should contribute to the stopped-flow fluorescence change characterizing the second exponential and show an increase in fluorescence similar but $75 \%$ smaller than that of wild-type gp43. This would be true in a case where the second exponential describes conformational changes within the holoenzyme with gp44/62 still associated. On the other hand, if the second step is the departure of gp44/62, the contribution to the FRET signal in step 10 is equal to summing the increase in FRET associated with the conformation change owing to binding between gp45 and gp43-4FW as well as the decrease in FRET associated with the departure of gp44/62 from the holoenzyme. Because the loss of FRET owing to the departure of gp44/62 from labeled gp45 is larger than the gain in the FRET signal from gp45 interacting with gp43-4FW, the experimental result is a small decrease in FRET corresponding to the dissociation of gp44/62. This result was hypothesized in previous studies through a large loss of interprotein FRET seen at step 10, ,,6 but can now be confirmed with our present results.

\section{Stoichiometries of ATP consumption}

\section{Investigation of the quenching protocols}

It appeared reasonable that the reported discrepancy in the amount and timing of ATP hydrolysis 


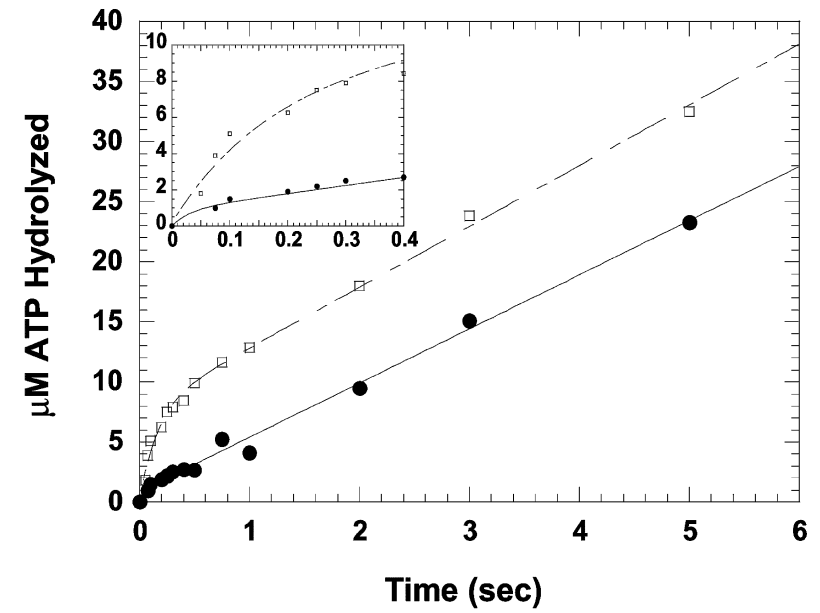

Figure 2. The presteady-state time-course in ATP hydrolysis in the presence of DNA using formic acid or $\mathrm{HCl}$ as the chemical quench was determined as described in Materials and Methods. $\mathrm{HCl}$ quenched samples were then extracted with phenol/chloroform and neutralized. Formic acid quenched samples were extracted with chloroform. The inlayed time-course magnifies the first 0.4 second of the larger plot to detail the burst phase. Final concentrations were $2 \mu \mathrm{M}$ gp44/62, $2 \mu \mathrm{M}$ gp45, $2 \mu \mathrm{M}$ Bio62/34/36mer, $2 \mu \mathrm{M}$ streptavidin, $10 \mathrm{mM} \mathrm{Mg}^{2+}, 500 \mu \mathrm{M}$ ATP, and $50 \mathrm{nM}\left[\gamma^{-32} \mathrm{P}\right]-\mathrm{ATP}$. Data points were fit to equation (5) which defines both the burst and steady-state rates as well as the magnitude of the burst. A higher burst in ATP consumption is obtained with $\mathrm{HCl}(--\square--)(7.6 \mu \mathrm{M})$ as opposed to formic acid ( $)(2.1 \mu \mathrm{M})$ as the quenching reagent. The dashed line is both the KinTekSim fit of the data to the reaction sequence shown in Figure 9 through step 7 and the fit to equation (5).

by the clamp-loader in the presence of the clamp protein might arise in data acquisition. There are two major differences in protocol between our previously reported experiments ${ }^{30}$ analyzing the ATP requiring reaction cycle for gp44/62 and gp45 and those of Pietroni et al. ${ }^{34}$ The first is in the nature of the quenching procedure. Ours uses $\mathrm{HCl}$ as a quenching agent followed by phenol/chloroform extraction and then neutralization by $\mathrm{NaOH} /$ Tris prior to TLC analysis of the reaction solution. Pietroni et al. uses formic acid as a quenching agent followed by chloroform extraction and then neutralization by Tris prior to TLC analysis. ${ }^{34}$ The fact that our substrate is $\left[\gamma^{-}{ }^{32} \mathrm{P}\right] \mathrm{ATP}$ and theirs is $\left[\alpha{ }^{32} \mathrm{P}\right]$ ATP is immaterial because satisfactory separation of the hydrolysis products is achieved in either case (see Supplemental Material). The second is the nature of the DNA substrate in which our system employs a streptavidin blocked biotinylated forked DNA while theirs is a simple primed DNA duplex, a point we will discuss later.

We initially investigated the potential impact of the differing quenching procedures (formic acid versus $\mathrm{HCl}$ ) on the measurement of the stoichiometries of ATP consumption. A series of transient kinetic experiments were performed using a rapid-
Table 2. Summary of transient kinetic measurements for ATP hydrolysis catalyzed by the gp44/62 protein complex in the presence of DNA using differing quenching agents

\begin{tabular}{lrrc}
\hline $\begin{array}{l}\text { Quench con } \\
\text { ditions }\end{array}$ & $\begin{array}{c}\text { Burst ampli } \\
\text { tude }(\mu \mathrm{M})^{\mathrm{a}, \mathrm{b}}\end{array}$ & $K_{\mathrm{obs}}\left(\mathrm{s}^{-1}\right)^{\mathrm{c}}$ & $\begin{array}{c}\text { Steady state } \\
\text { rate }\left(\mu \mathrm{M} \mathrm{s}^{-1}\right)^{\mathbf{d}}\end{array}$ \\
\hline Formic acid $^{\mathrm{e}}$ & $2.10 \pm 0.5$ & $10.7 \pm 5.2$ & $4.5 \pm 0.7$ \\
$\mathrm{HCl}^{\mathrm{f}}$ & $7.6 \pm 0.5$ & $8.5 \pm 2.3$ & $5.1 \pm 0.3$ \\
Formic acid $^{\mathrm{e}}$ & $1.5 \pm 0.3$ & $14.9 \pm 8.6$ & $3.3 \pm 0.2$ \\
$\begin{array}{l}\text { Formic acid } \\
\text { then } \mathrm{HCl}^{\mathrm{f}}\end{array}$ & $8.2 \pm 1.0$ & $8.2 \pm 3.9$ & $4.2 \pm 0.5$ \\
$\begin{array}{l}\text { Formic acid, } \\
\text { phenol/ } \mathrm{CHCl}_{3}\end{array}$ & $7.4 \pm 1.0$ & $12.0 \pm 5.0$ & $2.1 \pm 1.2$ \\
\hline
\end{tabular}

Assays for measuring the ATPase activity of the gp44/62 pro tein complex were performed in a rapid quench instrument as described in Materials and Methods. Final concentrations were $2 \mu \mathrm{M}$ gp44/62, $2 \mu \mathrm{M}$ gp45, $2 \mu \mathrm{M}$ Bio62/34/36mer, $2 \mu \mathrm{M}$ strep tavidin, $10 \mathrm{mM} \mathrm{Mg}{ }^{2+}, 500 \mu \mathrm{M}$ ATP, and $50 \mathrm{nM}\left[\gamma^{32} \mathrm{P}\right]$ ATP.

a Burst amplitudes in ATP hydrolysis were obtained from the fit of the data to the equation for a single exponential followed by a steady state rate (equation (5)). Refer to Materials and Methods for further details.

b The expected burst amplitude based upon the model pre viously presented for ATP dependent clamp loading is $8 \mu \mathrm{M}^{58}$

c Rate constants for the initial burst in ATP hydrolysis were obtained from the fit of the data to the equation for a single exponential followed by a steady state rate (equation (5)). Refer to Materials and Methods for further details.

d Steady state rates in ATP hydrolysis were obtained from the fit of the data to the equation for a single exponential followed by a steady state rate (equation (5)). Refer to Experimental Materials and Methods for further details.

e Chloroform extraction.

f Phenol/chloroform extraction.

quench instrument to accurately define the stoichiometry of ATP consumption as well as to observe the rate for initial ATP consumption, thus minimizing the extent of data extrapolation. In these experiments, a preincubated solution of $2 \mu \mathrm{M}$ accessory proteins, biotinylated DNA, and streptavidin (final concentration) was mixed versus a preincubated solution of $500 \mu \mathrm{M}$ ATP containing $50 \mathrm{nM}$ radiolabeled ATP (final concentration). The reactions were quenched with either formic acid or $\mathrm{HCl}$ at times ranging from 0.01 second to five seconds and further processed as previously described.

The resulting time-courses for ATP hydrolysis depicted in Figure 2 show a distinct dependency on the nature of the quenching agents. Specifically, the time-course in ATP consumption using $\mathrm{HCl}$ reveals a burst in ATP consumption of $7.6 \pm 0.5 \mu \mathrm{M}$ and is consistent with a stoichiometry of four molecules of ATP consumed per clamp loading event. The observed rate constant for the burst phase is $8.5 \pm 2.3 \mathrm{~s}^{1}$ and is faster than the rate constant of $\sim 2 \mathrm{~s}^{1}$ previously reported using similar reaction conditions $\mathrm{s}^{30}$ as a consequence of increased data collection. In contrast, the timecourse in ATP consumption using formic acid as the quenching agent yields a much reduced burst amplitude $(7.6 \pm 0.5 \mu \mathrm{M}$ versus $2.1 \pm 0.5 \mu \mathrm{M})$ (Figure 2) and reproduces the results reported by Pietroni et al. ${ }^{34}$ However, the observed rate constant 


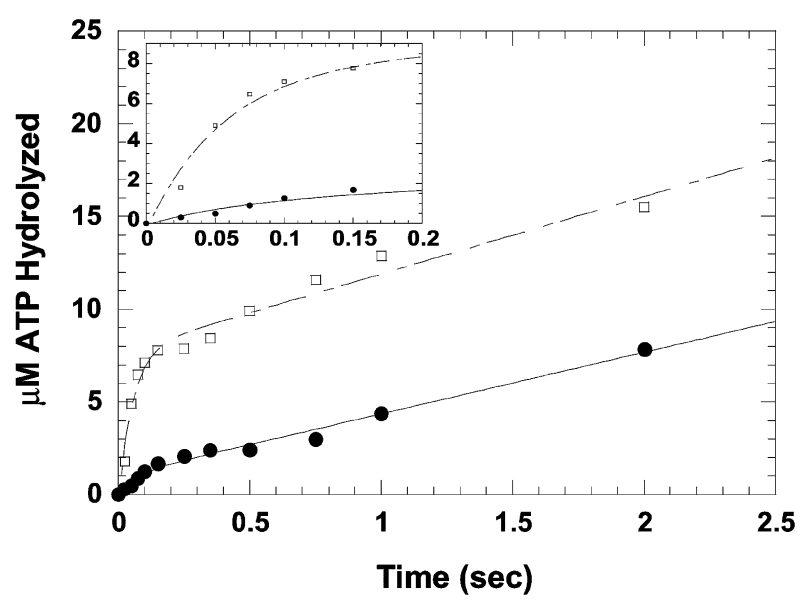

Figure 3. The presteady-state time-course in ATP hydrolysis in the presence of DNA using formic acid alone or followed by quenching with $\mathrm{HCl}$ (doublequench). The inlayed time-course magnifies the first 0.2 second of the larger plot to detail the burst phase. Assays were performed as described in Materials and Methods. Final protein concentrations were $2 \mu \mathrm{M}$ gp44/62, $2 \mu \mathrm{M}$ gp45, $2 \mu \mathrm{M}$ Bio62/34/36mer, $2 \mu \mathrm{M}$ streptavidin, $10 \mathrm{mM}$ $\mathrm{Mg}^{2+}, 500 \mu \mathrm{M}$ ATP, and $50 \mathrm{nM}\left[\gamma^{-32} \mathrm{P}\right]-$ ATP. Data points were fit to equation (5) which defines both the burst and steady-state rates as well as the magnitude of the burst. A higher burst in ATP consumption is obtained with $\mathrm{HCl}(--\square--)(8.2 \mu \mathrm{M})$ as opposed to formic acid ( $\bullet$ ) $(1.5 \mu \mathrm{M})$ as the quenching reagent.

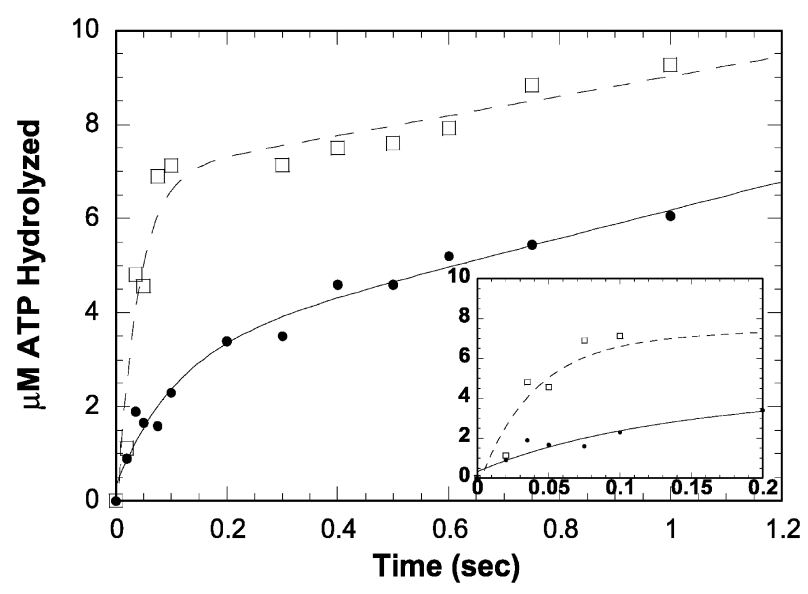

Figure 4. The presteady-state time-course in ATP hydrolysis in the presence of DNA using formic acid followed by the addition of chloroform or the combination phenol/chloroform was determined as described in Materials and Methods. The inlayed time-course magnifies the first 0.2 second of the larger plot to detail the burst phase. Final concentrations were $2 \mu \mathrm{M}$ gp44/62, $2 \mu \mathrm{M}$ gp45, $2 \mu \mathrm{M}$ Bio62/34/36mer, $2 \mu \mathrm{M}$ streptavidin, $10 \mathrm{mM} \mathrm{\textrm {Mg } ^ { 2 + }}, 500 \mu \mathrm{M}$ ATP, and $50 \mathrm{nM}\left[\gamma^{-32} \mathrm{P}\right]-A T P$. Data points were fit to equation (5) which defines both the burst and steady-state rates as well as the magnitude of the burst. Despite the use of formic acid as the initial quenching agent, a higher burst in ATP consumption is obtained with the extraction with phenol/chloroform $(--\square-$-) $(7.4 \mu \mathrm{M})$ as opposed to only chloroform ( $\bullet$ ) $(2.8 \mu \mathrm{M})$. for the burst phase overlaps that obtained using $\mathrm{HCl}$ as the quenching agent. Nearly identical steady-state rates for the continuing ATP hydrolysis are obtained using $\mathrm{HCl}$ or formic acid (Table 2 ). Hence the nature of the DNA substrate is not the cause of the discrepancy.

Further transient kinetic experiments were then performed to evaluate the reason for the differences in burst amplitudes apparently dependent upon the choice of quenching reagents. We hypothesized that the increased acidity of the $\mathrm{HCl}$ relative to formic acid quench might cause the complete release of the bound ADP and $\mathrm{P}_{\mathrm{i}}$ hydrolysis products. To test this concept, we repeated the above experiments in which the solution of accessory proteins and DNA were mixed versus a solution of ATP and quenched with formic acid, but the aliquot from each time point was further quenched with $\mathrm{HCl}$, extracted with phenol/chloroform and then neutralized by the addition of $\mathrm{NaOH} /$ Tris, i.e. a "double-quench" procedure. As depicted in Figure 3, the time-course for the control generated using solely the formic acid quench is biphasic, yielding a burst in ATP consumption of $1.5 \pm 0.3 \mu \mathrm{M}$ with an associated rate constant of $14.9 \pm 8.6 \mathrm{~s}^{1}$, and a steady-state rate of $3.3 \pm 0.2 \mu \mathrm{Ms}^{1}$. These values overlap those reported above. The time-course for ATP consumption using the double-quench procedure is also biphasic, but a significantly higher burst in ATP consumption $(8.2 \mu \mathrm{M}$ versus $1.5 \mu \mathrm{M})$ is observed consistent with additional $\mathrm{P}_{\mathrm{i}}$ being released from gp44/62. The higher burst amplitude, the burst rate constant as well as the steady-state rate for ATP hydrolysis are in satisfactory agreement with those reported above using $\mathrm{HCl}$ as the quenching agent (Table 2).

A second difference between the two quenching procedures arises in the choice of reagents in the extraction procedure: chloroform or chloroform/ phenol combination. To determine whether the $\mathrm{HCl}$ quench or the phenol-extraction procedure was responsible, a rapid-quench experiment in which the Pietroni et al. procedure ${ }^{34}$ was used with phenol included in the extraction gave the results shown in Figure 4 . The time-course is biphasic with a higher burst in ATP consumption relative to the Pietroni method $(7.4 \mu \mathrm{M}$ versus $2.8 \mu \mathrm{M})$. The burst rate constant $\left(12.0 \pm 5.0 \mathrm{~s}^{1}\right)$ and steady-state rate $\left(2.1 \pm 1.2 \mathrm{~s}^{1}\right)$ overlap with those listed in Table 2. The presence of phenol and not increased acidity (HCl versus formic acid), therefore, is necessary to release $\mathrm{P}_{\mathrm{i}} / \mathrm{ADP}$ from $\mathrm{a}$ specific complex within the reaction cycle. In both the $\mathrm{CHCl}_{3}$ and $\mathrm{CHCl}_{3}$ /phenol-extractions, the proteins appear as gelatinous precipitates at the organic $/ \mathrm{H}_{2} \mathrm{O}$ interface, and are not readily accessible in the case of the $\mathrm{CHCl}_{3}$ extraction, to further manipulation to capture additional hydrolysis products. We note in data not shown that the steadystate rate for continuing ATP hydrolysis at longer times is subject to inhibition by the accumulation of ADP as observed previously. ${ }^{35}$ 


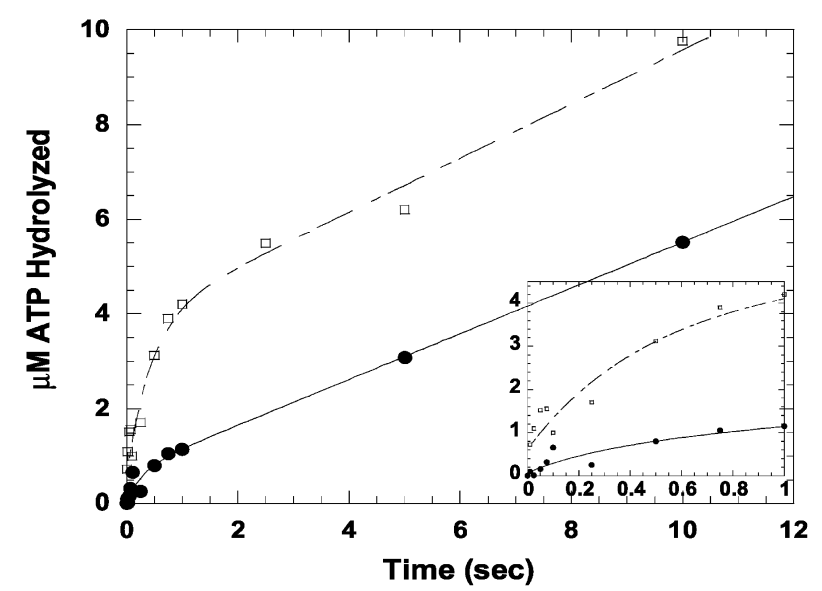

Figure 5. The presteady-state time-course in ATP hydrolysis in the absence of DNA using formic acid alone or followed by quenching with $\mathrm{HCl}$ (doublequench). The inlayed time-course magnifies the first 1.0 second of the larger plot to detail the burst phase. Assays were performed as described in Materials and Methods. Final protein concentrations were $2 \mu \mathrm{M}$ gp44/62, $2 \mu \mathrm{M}$ gp45, $10 \mathrm{mM} \mathrm{Mg}{ }^{2+}, 500 \mu \mathrm{M}$ ATP, and $50 \mathrm{nM}\left[\gamma^{-32} \mathrm{P}\right]-A T P$. Data points were fit to equation (5) which defines both the burst and steady-state rates as well as the magnitude of the burst. A higher burst in ATP consumption is obtained with the double-quench procedure (- $\square--)$ $(3.9 \mu \mathrm{M})$ as opposed to formic acid $(\bullet)(0.7 \mu \mathrm{M})$ as the quenching reagent. The burst rate for the doublequench procedure is $2.3 \pm 0.9 \mathrm{~s}^{1}$, while the steady-state rate is $0.57 \pm 0.07 \mathrm{~s}^{1}$. Larger errors in the burst rate were obtained when the formic acid quench was used. The burst rate for the formic acid alone is $3.2 \pm 3.0 \mathrm{~s}^{1}$, while the steady-state rate is $0.48 \pm 0.03 \mathrm{~s}^{1}$. The dashed line is both the KinTekSim fit of the data to the reaction sequence shown in Figure 9 through step 3 and the fit to equation (5).
A key issue is whether phenol catalyzed hydrolysis of ATP rather than the ATPase activity of the clamp-loader is responsible for the increased level of ATP hydrolysis in the presteady-state phase. If phenol were the catalyst, one might expect that rate constant for the burst of ATP consumption as well as the continuing steady-state rate for ATP hydrolysis to be exaggerated relative to the formic acid/chloroform procedure. The uncatalyzed hydrolysis of ATP was evaluated in a series of experiments in which a mixture of nonlabeled and radiolabeled ATP was allowed to age for a maximum of 30 minutes in either (1) $\mathrm{HCl}$ alone, (2) $\mathrm{HCl}$ and phenol/ $\mathrm{CHCl}_{3}$ prior to neutralization, or (3) $\mathrm{HCl}$, phenol/ $\mathrm{CHCl}_{3}$, and neutralization with $\mathrm{NaOH} /$ Tris. The above conditions were examined experimentally by TLC and the percentage of ATP hydrolyzed was calculated. In all cases, the results were essentially identical with relatively no change in the amount of ATP hydrolyzed between the various conditions over the time of our experimental measurements. This control experiment eliminates any concern that phenol or $\mathrm{HCl}$ causes background ATP hydrolysis and artificially increases the experimental burst data shown in Figures 2-4 with the various quenching and extraction procedures examined.

Finally, analogous transient experiments were performed by monitoring ATP consumption in the absence of DNA. The time-course generated using formic acid as the quenching agent is linear and has a poorly defined burst (Figure 5), in agreement with results originally reported by Pietroni et al. ${ }^{34}$ In contrast, as above, the time-course generated using our double-quench procedure is biphasic. The burst amplitude is $3.9 \pm 0.5 \mu \mathrm{M}$, yielding a stoichiometry of two ATP being hydrolyzed during the interaction of gp44/62 with gp45 in the absence of DNA as previously reported showing the need for phenol $/ \mathrm{CHCl}_{3}$ to release the hydrolysis products. The burst rate $\left(2.3 \pm 0.9 \mathrm{~s}^{1}\right)$ is better defined than previously by shorter quench times

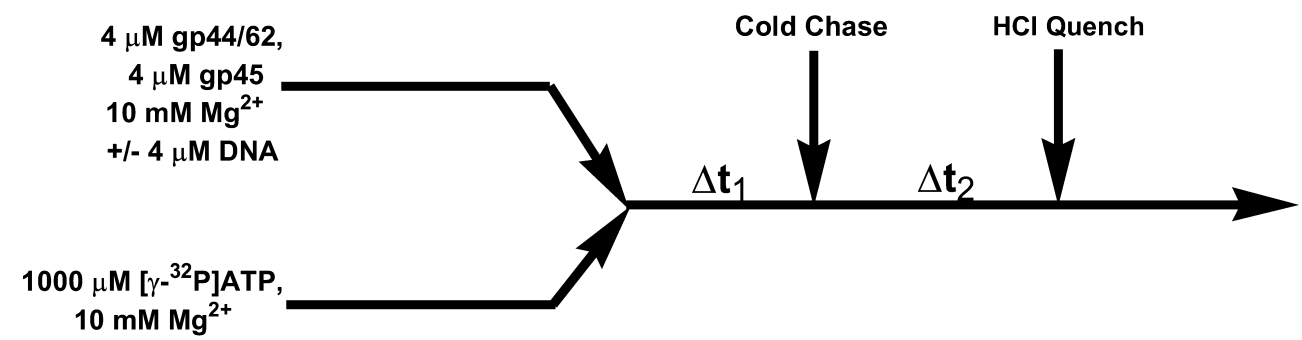

Figure 6. Pulse-chase rapid-quench scheme. Pulse-chase experiments were performed by mixing a preincubated solution of accessory proteins in the absence or presence of Bio62/34/36mer/streptavidin with ATP. In steady-state experiments, the reactants were mixed and allowed to react for five seconds $\left(\Delta t_{1}\right)$ prior to the addition of the cold chase (final concentration of $1 \mathrm{mM}$ ATP and $50 \mathrm{mM} \mathrm{Mg}^{2+}$ ). Aliquots of the reaction were then quenched at five second time intervals $\left(\Delta t_{2}\right)$ after the addition of cold chase using $\mathrm{HCl}$ as the chemical quench and processed as above. Transient pulse-chase experiments were performed as described above with the exception that the cold chase $(1 \mathrm{mM}$ unlabelled ATP with $\left.50 \mathrm{mM} \mathrm{Mg}{ }^{2+}\right)$ was added at 0.015 seconds $\left(\Delta t_{1}\right)$ through the quenching syringe (third syringe). After a delay of seven seconds $\left(\Delta t_{2}\right)$, the reaction was quenched through the manual addition of $100 \mu l 1 \mathrm{M} \mathrm{HCl}$. The samples were then extracted with $100 \mu \mathrm{l}$ phenol/chloroform and neutralized by the addition of approximately $35 \mu 1$ of $3 \mathrm{M} \mathrm{NaOH} / 1 \mathrm{M}$ Tris. 


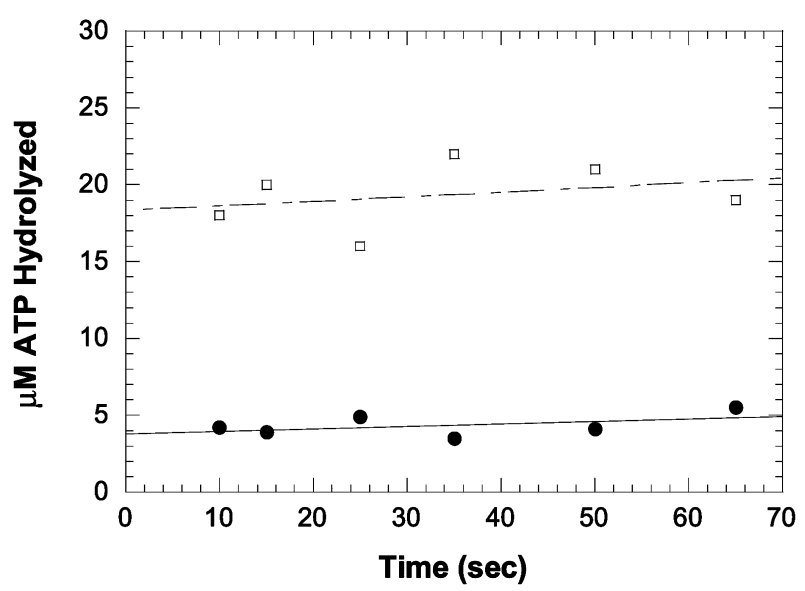

Figure 7. Pulse-chase kinetic analyses of ATP consumption by the bacteriophage $\mathrm{T} 4$ accessory proteins in the presence and absence of DNA. The steady-state time-course in ATP hydrolysis in the presence of Bio62/ 34/36mer (- - $\square-$-) using cold ATP chase was determined as described in Materials and Methods. Final concentrations were $2 \mu \mathrm{M}$ gp44/62, $2 \mu \mathrm{M}$ gp45, $2 \mu \mathrm{M}$ Bio62/

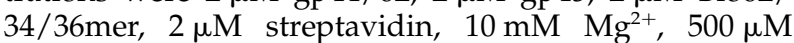
ATP, and $50 \mathrm{nM}\left[\gamma^{-32}\right] \mathrm{P}$-ATP. The steady-state time-course in ATP hydrolysis in the absence of DNA ( $\bullet$ ) using cold ATP chase was determined as described in Materials and Methods. Reactions were allowed to proceed for five seconds $\left(\Delta t_{1}\right)$ before addition of the cold chase. Aliquots of the reactions were then quenched at times ranging from five to 65 seconds $\left(\Delta t_{2}\right)$.

(Figure 5). Similar steady-state rates were observed for either the formic acid quench $\left(0.48 \pm 0.03 \mathrm{~s}^{1}\right)$ or the double-quench $\left(0.57 \pm 0.07 \mathrm{~s}^{1}\right)$ procedures.

\section{Pulse-chase kinetic analysis}

\section{Examination of the stoichiometry of ATP hydrolysis in the presence of DNA}

The difference ( 2 versus 4 ) in the equivalents of ATP hydrolyzed by the clamp-loader in the absence and presence of DNA prompted us to examine whether the two remaining ATP sites exchanged bound ligand with solution before turnover. In a pulse-chase procedure, a large excess of unlabeled ATP (cold trap chase) is introduced into the solution mixture after ATP turnover by gp44/ 62 has reached the steady-state. The partioning of the gp44/62.2ATP* complex (where labeled ATP* occupies the remaining two ATP-binding sites) to form products (ADP) or to release substrate (ATP) then can be measured, because unlabeled chase ATP dilutes any dissociated substrate. Consequently, gp44/62.2ATP will be unlabeled and the $\mathrm{ADP} / \mathrm{P}_{\mathrm{i}}$ products are undetectable in the assay system.

Figure 6 describes the experimental procedure for the pulse-chase experiments. It is important to establish that introduction of the unlabelled ATP chase sufficiently dilutes out the labeled ATP pulse. Figure 7 provides an example of a steadystate time-course for ATP hydrolysis by the acces- sory proteins in the presence of DNA using the cold trap chase technique in which $\Delta t_{1}$ is held at five seconds and $\Delta t_{2}$ is varied. Clearly, dilution by the ATP chase is sufficient, because the apparent steady-state rate of ATP hydrolysis after the addition of chase is essentially zero $\left(0.03 \pm 0.02 \mu \mathrm{M} \mathrm{s}^{1}\right)$. Extrapolation to time zero yields an apparent burst in ATP consumption of approximately $16 \mu \mathrm{M}$ reflecting the time at which the chase was introduced. The ATP consumed during the five seconds prior to introduction of the cold chase can be calculated from the presteady-state and steady-state rates for ATP hydrolysis (present and published values) (30,32 $^{3}$ and is approximately $16 \mu \mathrm{M}$. The agreement between these data collectively indicates that all four ATPase sites have turned over twice within five seconds. Because in the pulse-chase studies the ATPase activity of gp $44 / 62$ is effectively quenched and the hydrolysis products released by dilution with chase and not an acid quench protocol, the consistency in the collective acquired data further rules against artifactual hydrolysis of ATP induced by the $\mathrm{HCl}$ quench phenol/chloroform combination.

Recall that gp44/62 hydrolyzes two molecules of ATP in the absence of DNA while in the presence of DNA as shown above, all four ATPase sites rapidly hydrolyze ATP. The question remains as to whether all four ATPase sites partition to form ADP in the absence of DNA, or whether the remaining two ATPase sites freely exchange ligand with solution during or after the initial hydrolysis of the first 2 ATP equivalents. Pulse-chase experiments were performed to evaluate the stoichiometry of ATP consumed by the gp44/62 complex interacting with the gp 45 protein in the absence of DNA. Figure 7 illustrates the steady-state timecourse for ATP hydrolysis by the accessory proteins in the absence of DNA using the cold ATP chase again with $\Delta t_{1}$ held constant at five seconds and $\Delta t_{2}$ being varied. The flat time-course for the cold chase again reflects that dilution is sufficient to abolish the apparent steady-state rate; extrapolation of the time-course to zero time gives a value of $3.7 \pm 0.2 \mu \mathrm{M}$. If all four sites in the gp44/62 complex hydrolyzed labeled ATP without exchange with the cold chase, then this value should have been at least $8 \mu \mathrm{M}$. Consequently, after hydrolysis of the initial two molecules of $\left[\gamma^{-}{ }^{32} \mathrm{P}\right] \mathrm{ATP}$, the remaining two $\left[\gamma^{32} \mathrm{P}\right] \mathrm{ATP}$ molecules are exchanged with the cold ATP from solution.

The interpretation of these experiments could potentially be compromised if the high concentration of ATP and $\mathrm{Mg}^{2+}$ in the chase acts as a quenching agent by denaturing and/or inactivating the enzyme. Control experiments were thus performed to evaluate if the gp44/62 protein was active in the presence of $20 \mathrm{mM}$ ATP. In these experiments, $5 \mu \mathrm{M}$ Bio62/34/36mer was added to the reaction ten seconds after the addition of cold chase. Aliquots of the reaction were quenched 


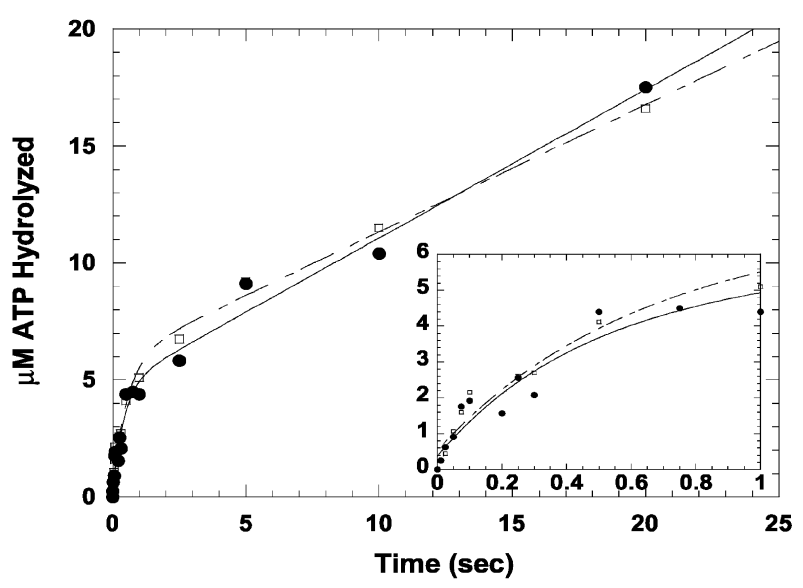

Figure 8. The presteady-state time-course in ATP hydrolysis in the absence of DNA measured through pulse-chase or chemical quench conditions as described in Materials and Methods. The inlayed time-course magnifies the first 1.0 second of the larger plot to detail the burst phase. Final concentrations were $2 \mu \mathrm{M}$ gp44/62,

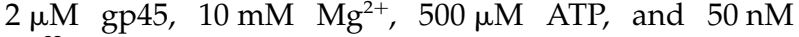
$\left[\gamma^{-32} \mathrm{P}\right]-A T P$. Reactions were allowed to proceed for 0.0120 seconds $\left(\Delta t_{1}\right)$ before addition of the cold chase. Aliquots of the reaction were then quenched with formic acid ( $\bullet$ ) or $\mathrm{HCl}(--\square--)$ seven seconds later $\left(\Delta t_{2}\right)$. Samples quenched with formic acid were treated with $\mathrm{CHCl}_{3}$, and samples quenched with $\mathrm{HCl}$ where then treated with phenol $/ \mathrm{CHCl}_{3}$ and neutralized with $\mathrm{NaOH} /$ Tris. Data points were fit to equation (5) which defines both the burst and steady-state rates as well as the magnitude of the burst. An identical burst in ATP consumption is obtained through either pulse-chase experiment $(\sim 4 \mu \mathrm{M})$. Identical burst rates $\left(\sim 2 \mathrm{~s}^{1}\right)$ and steady-state rates $\left(\sim 0.6 \mathrm{~s}^{1}\right)$ were also obtained in either case.

from time points encompassing 1-20 minutes after the addition of DNA and monitored for the production of radiolabeled phosphate which would be an indication of ATP hydrolysis. In this protocol, the addition of DNA stimulates the ATPase activity of gp44/62 so that any radiolabeled ATP would eventually be hydrolyzed after long incubation times. Figure S2 in Supplemental Material illustrates the TLC analysis used to demonstrate that ATP is still being consumed, thus, indicating that the accessory proteins are not denatured and/or inactivated by the cold chase.

A third pulse-chase experiment was carried out where $\Delta t_{1}$ was varied and $\Delta t_{2}$ fixed at seven seconds, sufficient for any bound labeled ligands to proceed through the reaction cycle or dissociate. The objective was twofold: firstly to more accurately define the stoichiometry of ATP turnover and secondly, to determine whether the gp44/ 62.ADP. $\mathrm{P}_{\mathrm{i}}$ complex is formed reversibly. If the latter holds, then the presence of kinetic barriers to its further progress along the reaction cycle might result in significant partitioning of the labeled complex back to labeled ATP. This would be manifest in a decreased amount of $P_{i}$ product at $\Delta t_{2}$ under conditions of the pulse chase study relative to $P_{i}$
Table 3. Simulated rate ranges for bacteriophage $\mathrm{T} 4$ DNA polymerase holoenzyme assembly

\begin{tabular}{|c|c|c|c|}
\hline Step $^{a}$ & Species formed & $\begin{array}{c}\text { Forward rate } \\
\text { constant }^{\mathbf{b}}\end{array}$ & $\begin{array}{l}\text { Reverse rate } \\
\text { constant }^{\mathrm{b}}\end{array}$ \\
\hline 1 & $\begin{array}{c}\text { gp45'.gp44/ } \\
62(4 \mathrm{ATP})\end{array}$ & $\begin{array}{c}160 \\
240 \mu \mathrm{M}^{-1} \mathrm{~s}^{-1}\end{array}$ & $7090 \mathrm{~s}^{-1}$ \\
\hline 2 & $\begin{array}{l}\text { gp45. } 5^{\mathrm{c} p} 44 / \\
62(4 \mathrm{ATP})\end{array}$ & $80100 \mathrm{~s}^{-1}$ & $4050 \mathrm{~s}^{-1}$ \\
\hline $3^{c}$ & $\begin{array}{c}\text { gp45‥gp44/ } \\
62(2 \mathrm{ATP})\end{array}$ & $28 \mathrm{~s}^{-1}$ & $\mathrm{~N} / \mathrm{A}^{\mathrm{d}}$ \\
\hline 4 & $\begin{array}{l}\text { gp45․p } \\
\text { 62(2ATP).DNA }\end{array}$ & $\begin{array}{c}120 \\
180 \mu \mathrm{M}^{-1} \mathrm{~s}^{-1}\end{array}$ & $511 \mathrm{~s}^{-1}$ \\
\hline 5 & $\begin{array}{c}\text { gp45'.gp44/ } \\
\text { 62(2ATP).DNA }\end{array}$ & $150250 \mathrm{~s}^{-1}$ & $N / A^{d}$ \\
\hline $6^{c}$ & $\begin{array}{c}\text { gp } 45^{\mathrm{H}} \cdot \mathrm{gp} 44 / \\
62 \cdot \mathrm{DNA}\end{array}$ & $719 \mathrm{~s}^{-1}$ & $N / A^{d}$ \\
\hline 7 & $\begin{array}{l}\text { gp45.gp44/ } \\
\text { 62.DNA }\end{array}$ & $0.51 .0 \mathrm{~s}^{-1}$ & $N / A^{d}$ \\
\hline 8 & $\begin{array}{l}\text { gp45'.gp44/ } \\
\text { 62.DNA.gp43 }\end{array}$ & $\begin{array}{c}300 \\
500 \mu \mathrm{M}^{-1} \mathrm{~s}^{-1}\end{array}$ & $515 \mathrm{~s}^{-1}$ \\
\hline 9 & $\begin{array}{l}\text { gp } 45^{\mathrm{K}} \cdot \mathrm{gp} 44 / \\
62 \cdot \mathrm{DNA} \cdot \mathrm{gp} 43\end{array}$ & $40100 \mathrm{~s}^{-1}$ & $110 \mathrm{~s}^{-1}$ \\
\hline 10 & gp45'DNA.gp43 & $0.53 \mathrm{~s}^{-1}$ & $N / A^{d}$ \\
\hline 11 & $\begin{array}{l}\text { gp } 45^{\mathrm{A}} \pm \mathrm{gp} 44 / \\
62 \pm 2 \mathrm{ATP}\end{array}$ & $0.20 .3 \mathrm{~s}^{-1}$ & $\mathrm{~N} / \mathrm{A}^{\mathrm{d}}$ \\
\hline 12 & $\begin{array}{c}\text { gp } 45^{\mathrm{A}} \pm \mathrm{gp} 44 / \\
62 \pm \mathrm{DNA}\end{array}$ & $0.080 .12 \mathrm{~s}^{-1}$ & $\mathrm{~N} / \mathrm{A}^{\mathrm{d}}$ \\
\hline 13 & $\begin{array}{c}g p 45^{\mathrm{A}} \pm \mathrm{gp} 44 / \\
62 \pm \mathrm{gp} 43\end{array}$ & $0.010 .05 \mathrm{~s}^{-1}$ & $\mathrm{~N} / \mathrm{A}^{\mathrm{d}}$ \\
\hline
\end{tabular}

a Steps are shown in Figure 9(c).

b The range of rate constants provides satisfactory simu lations of the data described here and include those values from previous reports. ${ }^{5,6,32}$ Values outside this range signifi cantly affect the quality of the simulation.

c These steps are assigned to ATP hydrolysis events.

d These steps are assigned as not applicable because addition of a reverse rate constant decreased the quality of the fit or are assumed to be irreversible.

product formed in studies using only a direct quenching procedure. Consequently, a series of transient pulse-chase experiments were carried out to investigate the amplitude of the transient phase as well as the associated presteady-state rate. Moreover, note the release of the hydrolysis products was by cold chase and not by phenol which was omitted from the formic acid quench protocol thus eliminating the possibility that hydrolysis of bound ATP is being induced by the quenching protocol. For comparison, the series included the standard $\mathrm{HCl}$ quench procedure.

The results are depicted in Figure 8 and are nearly identical with the $\mathrm{HCl} / \mathrm{Phenol} / \mathrm{CHCl}_{3}$ treated samples (Figure 5). The data are biphasic with a burst amplitude of $5.3 \pm 0.4 \mu \mathrm{M}$ and a rate constant of $1.8 \pm 0.4 \mathrm{~s}^{1}$ for those treated with $\mathrm{HCl}$ at $\Delta t_{2}$ and a burst amplitude of $4.4 \pm 0.5 \mu \mathrm{M}$ and a rate constant of $2.3 \pm 0.7 \mathrm{~s}^{1}$ for those treated with formic acid at $\Delta t_{2}$. The burst amplitude is consistent with the anticipated value of $4 \mu \mathrm{M}(2 \times 2 \mu \mathrm{M}$ gp44/62), and the observed rate constant for both the pre- and steady-state phases is in satisfactory agreement. There is no evidence, therefore, for a decreased level of $P_{i}$ throughout the observed time-course as a consequence of the pulse-chase/ quench procedure relative to direct quenching so 
(a)

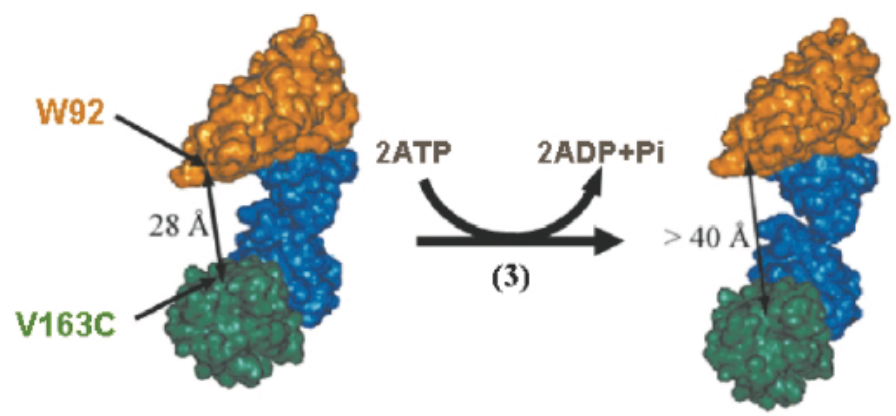

(b)

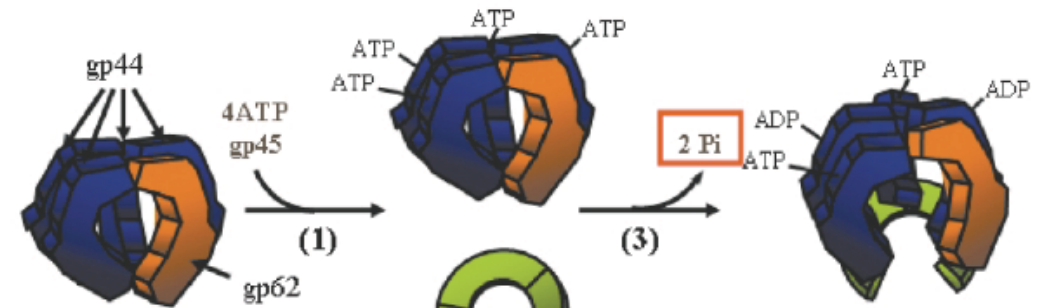

gp62

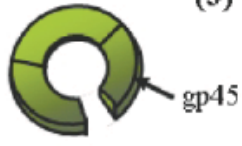

(4) $\mathrm{DNA}-2 \mathrm{Pi}$

(6)

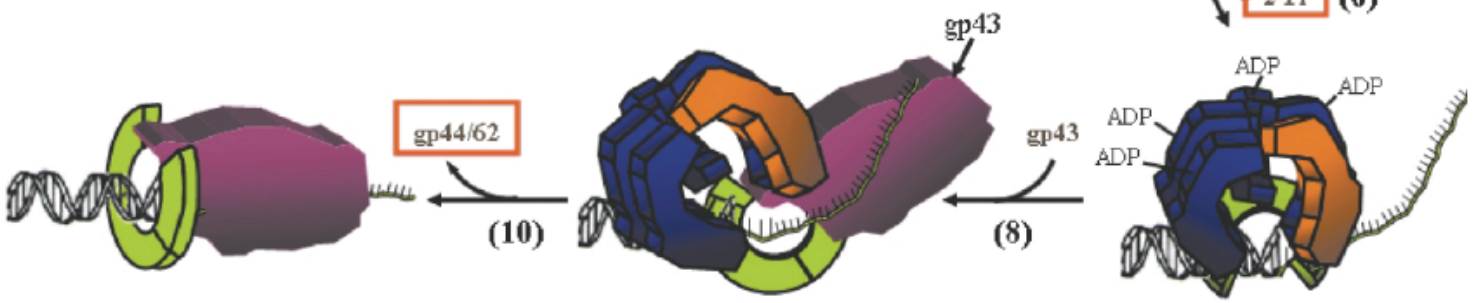

(c)

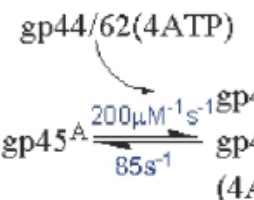

(1)

(2)

(4ATP)

$$
\mathrm{gp} 45^{\mathrm{A}}+\mathrm{gp} 44 / 62+2 \mathrm{ATP}
$$

(11)

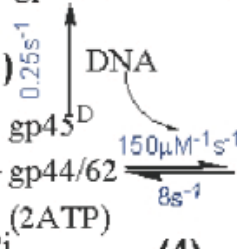

(3) $2 \mathrm{Pi}$

(4)

$\begin{array}{ll}\mathrm{gp} 45^{\mathrm{E}} & \mathrm{gp} 45^{\mathrm{F}} \\ \mathrm{gp} 44 / 62 & 200 \mathrm{~s}^{-1} \\ \text { (2ATP) } & \mathrm{gp} 44 / 62 \\ \text { (2ATP) } \\ \text { DNA }\end{array}$

(5)

DNA

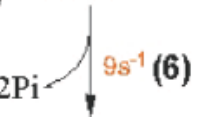

(10)

$$
\begin{aligned}
& \text { gp45 } \\
& \text { gp44/62 } \\
& \text { DNA } \\
& \text { gp43 }
\end{aligned}
$$

(9) $\mathrm{gp} 45^{\mathrm{I}}$

(8)

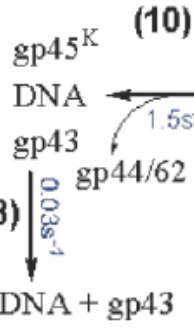

$44 / 62 \quad 5 s^{-1}$ gp $44 / 62$

$\overbrace{\mathrm{gp} 43}^{10 \mathrm{~s}^{-1}}$

$\mathrm{gp} 45^{\mathrm{H}}$

(7)

7) $45^{\mathrm{G}}$

$\begin{array}{ll}\text { gp } 44 / 62 \div & \text { gp } 44 / 62 \\ \text { DNA } & \text { DNA }\end{array}$

gp43

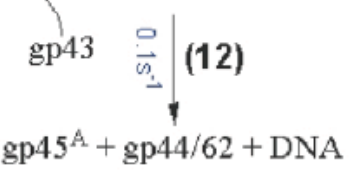

Figure 9. Representation of the bacteriophage T4 DNA polymerase holoenzyme assembly process. (a) Details the opening of the clamp in step 3 as measured by FRET between W92 and CPM attached to V163C of gp45 and highlights the importance of ATP hydrolysis in opening the subunit interface of the clamp wide enough to be loaded onto DNA. (b) A proposed structural representation of the holoenzyme assembly process. Steps 1, 3, 4, 6, 8, and 10 are depicted. Red boxes highlight the important conclusions from this paper namely the hydrolysis of ATP in step 3 to open the clamp, the hydrolysis of ATP in step 6 to close the clamp around DNA, and the dissociation of gp44/62 from the holoenzyme in step 10. (c) The sequential ATP driven reaction cycle for loading of the gp 45 clamp by the gp $44 / 62$ clamp-loader onto DNA followed by the capture of the gp43 polymerase and dissociation of the clamp-loader. Individual rates are an average of simulated rates from this paper as well as those found previously. ${ }^{5,6,30,32}$ Steps are identified by numbers 113 and individual states of holoenzyme assembly are designated by letters $A \mathrm{~K}$. 
no conclusion may be drawn about the reversibility of the gp44/62.gp $45 \cdot A D P \cdot P_{i}$ complex.

\section{Kinetic simulation of experimental FRET and ATP quench data}

Experimental stopped-flow FRET traces and rapid-quench ATPase data were simulated when indicated in the corresponding figure legends using KinTekSim applied to the kinetic sequence shown in Figure 9(c). The range of rate constants characteristic of each step from these and earlier data are listed in Table 3 and are from this and previous studies. ${ }^{5,6,32}$ The interprotein stopped-flow FRET experiment between gp45 and gp44/62 used to detect the dissociation of gp44/62 from the multiprotein complex at step 9, Figure 9 was simulated using a partial mechanism which included steps $8-10$. The reactions quenched with $\mathrm{HCl}$, extracted with phenol/ $\mathrm{CHCl}_{3}$, and neutralized with $\mathrm{NaOH}$ in the absence and presence of DNA shown in Figures 2 and 5 were simulated using KinTekSim. In the absence of DNA, the rapid quench data from Figure 5 was simulated using steps $1-3$ in Figure 9. In the presence of DNA, the rapid quench data from Figure 2 was simulated using steps 1-7 in Figure 9. Rate constants were individually varied to determine the best fit of the simulated rates to the experimental data. Irreversible rates were assigned when the inclusion of a reverse rate constant decreased the overall quality of the simulation. Note that ADP is not explicitly shown in the kinetic sequence because its dissociation rate has not been defined.

\section{Discussion}

We are able to reconfirm and expand on the molecular mechanism of holoenzyme formation in bacteriophage T4. Our current structural representation of holoenzyme assembly is depicted in Figure 9 along with the accompanying kinetic sequence. It highlights the significant findings from this paper which include: (1) the need for ATP hydrolysis to open the clamp sufficiently wide for its facile loading onto a primer/template DNA, (2) the role of the clamp-loader as a chaperone which leaves the multicomponent complex after the clamp and the polymerase are properly aligned, and (3) the requirement of sequential hydrolysis of two molecules of ATP by the clamploader before and after interaction with DNA for a total of 4 equivalents.

We had previously proposed a model for the ATP-dependent process of clamp-loading catalyzed by the gp44/62 protein complex. ${ }^{35,36}$ In this model, the gp44/62 protein complex acts as a molecular motor by transferring the chemical energy derived from the hydrolysis of ATP into mechanical energy required to load the clamp onto duplex DNA. The dynamics of this model were based in part upon results which quantitatively evaluated the stoichiometry and kinetics of ATP hydrolysis during the process of clamp loading and holoenzyme assembly. ${ }^{30,32}$ Transient kinetic analyses of the ATPase activity of the gp44/62 clamp loading complex revealed that all four bound ATP molecules are hydrolyzed during the process of clamp loading. ${ }^{32}$ Further kinetic studies indicated that ATP hydrolysis is sequential in which two molecules of ATP are consumed during the association of gp44/62 with gp45 (step 3) prior to association with DNA (step 4). ${ }^{32}$ By inference, the remaining two molecules of ATP were proposed to be hydrolyzed upon association of the formed gp44/ 62.gp45 binary complex with DNA. Once clamp loading is complete, the T4 DNA polymerase rapidly associates with the gp45 "clamp protein" to form the holoenzyme complex in an ATP-independent process. ${ }^{32,35,36}$

\section{Four equivalents of ATP are hydrolyzed by gp44/62 during holoenzyme assembly}

Although the dynamics of the ATPase reaction cycle model have been further corroborated by a variety of augmenting functional studies, ${ }^{5,6}$ a recent report by Pietroni et al. ${ }^{34}$ had cast doubt upon this model. A modified kinetic scheme was proposed based upon differences in the stoichiometries of ATP consumption during the process of clamp loading, so that ATP is not consumed during the interaction of gp44/62 with gp45, and only one ATP equivalent is consumed during clamp loading onto duplex DNA.

In these present studies, we used a higher concentration $(2 \mu \mathrm{M})$ of accessory proteins and DNA than earlier to provide a more accurate determination of the stoichiometries and rate constants in ATP consumption during the process of clamp loading. Secondly, we endeavored to obtain data points during the burst phase to minimize extrapolation errors. Finally, we performed a direct comparison of differing quenching reagents $(\mathrm{HCl}$ versus formic acid) and extraction procedures $\left(\mathrm{CHCl}_{3}\right.$ versus phenol/ $\left.\mathrm{CHCl}_{3}\right)$ in order to evaluate whether this was a possible source for the reported discrepancies in ATP stoichiometries.

We have been able to reproduce the two sets of published data reported for the ATP driven reaction cycle of clamp-loading using either the formic acid $^{34}$ or $\mathrm{HCl}$ quench protocols. ${ }^{30,32}$ Whereas the time-course for ATP hydrolysis by gp44/62 with the formic acid quench procedure gives a poorly defined burst of ATP in the absence of DNA and approximately one ATP equivalent rapidly hydrolyzed in the presence of DNA, the same timecourse with the $\mathrm{HCl}$ quench procedure shows 2 and 4 equivalents of ATP consumption in the absence and presence of DNA, respectively. Through a series of experiments systematically varying the constituents of the quench solution, we have traced the differences in behavior to the need for phenol to denature the gp44/ 62.gp45.ADP. $\mathrm{P}_{\mathrm{i}}$ species for product release (Figures 
$2-5)$. The added fact that either the double-quench procedure (formic/ $\mathrm{CHCl}_{3}$ acid followed by $\mathrm{HCl}$ / phenol/ $\left.\mathrm{CHCl}_{3}\right)$ or the inclusion of phenol in the formic acid quench method release additional $P_{i}$ (and presumably ADP) strongly supports this interpretation. The possibility that phenol catalyzes the conversion of a gp45.gp44/62.ATP species to hydrolysis products is discounted by the results of the pulse-chase experiments cited below. Moreover, because there is good agreement between the equivalents of ATP bound and those that hydrolyze in the presteady-state there must be negligible concentration of gp45.gp44/62.ATP.DNA during active turnover (steady-state).

Because gp44/62 initially binds four molecules of $\mathrm{ATP}^{31}$ there are at least two possible explanations to account for the finding of only 2 equivalents of ATP being hydrolyzed in the absence of DNA. Two models that can be distinguished by steady-state pulse-chase experiments include; (1) the gp44/62 "tetramer" displays half-of-thesites reactivity such that the enzyme hydrolyzes all the initially four bound ATP but in two independent events one of which is fast relative to subsequent kinetic steps and the second may set the rate limiting step; (2) the gp44/62 tetramer hydrolyzes two of the four bound ATP during association of the clamp, but in the absence of DNA, the remaining 2 equivalents of ATP are rapidly exchanged with the solution pool before hydrolysis. Our data (Figure 7) are consistent with the second model, suggesting that bound DNA may prevent exchange from these sites and also corroborates the stoichiometry of ATP hydrolysis observed in the rapid-quench experiments.

The pulse-chase study depicted in Figure 8 which includes both pre- and steady-state phases tracks the liberation of labeled $\mathrm{P}_{\mathrm{i}}$ as a consequence of rapidly diluting the labeled ATP with unlabeled ATP acting as a quench, so that only labeled ATP bound to gp44/62 at the time of the chase addition may convert to labeled $\mathrm{P}_{\mathrm{i}}$. The fact that the timecourse in which phenol was deliberately omitted from the formic acid $/ \mathrm{CHCl}_{3}$ quenching protocol (which now simply stops further turnover) overlaps data for the $\mathrm{HCl} /$ phenol $/ \mathrm{CHCl}_{3}$ quench procedure eliminates the possibility that phenol increases the hydrolysis of ATP bound to gp44/62. The agreement between the chemical quench and pulse-chase studies with respect to ATP equivalents hydrolyzed throughout their overlapping time-courses indicates there is no measurable amount of gp44/62.ADP.P $P_{i}$ that dissociates via reversible formation of the gp44/62.ATP complex. We cannot, however, conclude that the hydrolysis is not reversible.

Some light may be shed on to the question as to why phenol is needed to release totally the $P_{i}$ (and presumably the ADP) hydrolysis products from the gp44/62-gp45.ADP.P $P_{i}$ species by the finding that $P_{i}$ does not inhibit the ATPase activity of gp44/62. ${ }^{35}$ One interpretation of this result is that the dissociation of $P_{i}$ from a gp44/62.ADP. $P_{i}$ com- plex is coupled to a conformational change that greatly decreases the affinity of the enzyme's site for the ligand. Whether both product ligands are sequestered within a sterically inaccessible complex can only be unequivocally solved by knowing the actual structure of this species.

The key rapid-quench data in Figures 2 and 5 can be readily simulated by KinTekSim using the applicable kinetic steps. The range of rates providing satisfactory fits of the collective data ${ }^{5,6,32}$ are depicted in Table 3 . The average of rate constants from Table 3 is shown above the arrows in Figure 9(c). The two steps involving ATP hydrolysis (steps 3 and 6) are rapid relative to the succeeding steps (7, 11, and 12) allowing their detection through biphasic kinetics. Although the data interpretation by Pietroni et al. is compromised by their failure to observe the ATP hydrolysis steps, nevertheless, their values for the kinetic steps (1, 3-6) are in satisfactory agreement with ours. In pulse-chase experiments conducted by Pietroni et al. where ATP serves as a quenching agent, $\sim 1$ hydrolyzed equivalent of ATP was found and probably corresponds to step 3 because the rapid loss of gp45 from an unblocked primer template DNA (step 12) would prevent observation, as noted,,$^{34}$ of the hydrolysis event in step 6. Ironically, the collective data is in close agreement with previous work from the von Hippel laboratory that had been amended. ${ }^{31}$

\section{Linking ATP hydrolysis to clamp opening}

Expanding on an earlier study by Alley et al., ${ }^{5}$ we recently triangulated through various FRET pairs situated at the clamp protein subunit interface the conformation of gp 45 at the various stages of the clamp-loader/clamp reaction cycle, ${ }^{6}$ which is illustrated in Figure 9(a) and (b). The transition from gp $45^{\mathrm{B}}$ to gp $45^{\mathrm{D}}$ is accompanied by an increase in intrasubunit distance from $\sim 28 \AA$ to $>40 \AA$ to readily accommodate duplex DNA $(\sim 30 \AA)$; addition of DNA closes gp $45^{\mathrm{D}}$ in a series of steps to an out of plane conformation $\left(\mathrm{gp} 45^{\mathrm{H}}\right)$ orthogonal to the groove of DNA. Finally, addition of gp43 closes gp $45^{\mathrm{H}}$ to an in-plane conformation $\left(\mathrm{gp} 45^{\mathrm{K}}\right)$, leaving $11 \AA$ between subunits. ${ }^{6}$ The overall sequence includes a step involved with the hydrolysis of ATP linking that event to clamp opening/closing. We now measured the magnitude of the opening of the subunit interface of gp45 in the presence of gp44/62 and different ATP analogs. The opening of the clamp (step 3 in Figure 9) is not observed when either ADP or ATP $\gamma$ S is used in place of ATP, suggesting that it is the hydrolysis and not the binding of ATP which leads to the opening of the clamp. These findings are consistent with the detection of ATP hydrolysis in clamp opening/loading onto DNA by the rapid-quench experiments and conformational changes in the gp44/62.gp45 complex that occur as a consequence of ATP hydrolysis. ${ }^{37}$ 


\section{The role of gp44/62 includes a chaperone activity}

The release of gp44/62 from the holoenzyme was suggested to occur during step 10 (Figure 9) due to the loss of a significant amount of interprotein FRET. ${ }^{5}$ By utilizing this property, we were able to measure directly the rate of dissociation of gp44/62 from the multiprotein complex, gp44/ 62.gp45.DNA.gp43, revealing a role for gp $44 / 62$ as a molecular chaperone. Previous results identified gp44/62 as a chaperone ${ }^{13}$ and a molecular motor, ${ }^{35}$ but the exact timing of its departure had not been identified conclusively. The inability to fluorescently label gp44/62 as a functional entity required an alternate way of measuring interprotein FRET.

In this case, we utilized the native tryptophans within gp44/62 as the fluorescent donors and detected energy transfer to a coumarin acceptor attached to a mutant of gp45 devoid of any tryptophan residues. We minimized the interprotein FRET contribution arising from gp43 by replacing tryptophan with $4 \mathrm{FW}$. Incorporation of $4 \mathrm{FW}$ into gp 43 resulted in a DNA polymerase holoenzyme in which the appreciable tryptophan donors for interprotein FRET resided in gp44/62. In this way, we were able to monitor the distance changes between gp45 and gp44/62 and correlate the decrease in fluorescence in Figure 1 as the dissociation of gp44/62 from the holoenzyme. The fraction of remaining tryptophan residues in gp43-4FW, furthermore, allowed us to identify formation of a multiprotein complex at state J (Figure 9), through the similarity in the observed rates as well as in the degree of fluorescent increase when comparing gp43 and gp43$4 \mathrm{FW}$. The ratio of the normalized change (relative to gp43) in fluorescence intensity (23\%) found in step 9 correlates well with the residual tryptophans in gp43-4FW (25\%). Although similar rates are observed for gp43 and gp43-4FW in step 10, the opposite magnitude of the fluorescent change allowed us to conclude that the disappearance in FRET was due to the dissociation of gp44/62 from the holoenzyme complex. Gp44/62 acts catalytically to load gp45 onto DNA, confirming earlier speculation that gp44/62 did not remain a part of the functional holoenzyme. ${ }^{5,6,13}$

The molecular rearrangements in gp44/62 required to perform its chaperone function have yet to be identified but are expected to be complex. Gp44/62 is a large protein complex $(123 \mathrm{kDa})$ yet must allow gp43 to interact with gp45 in the formation of a functional holoenzyme. ${ }^{3}$ This rearrangement happens in the absence of ATP hydrolysis or binding and is presumed to occur through protein affinity only. Crosslinking data between gp45 to both gp44/62 and gp43 identifies only one face of gp45 that interacts with both proteins. ${ }^{37-40}$ The movement of gp44/62 along one face of gp45 fostering gp43 binding has yet to be structurally determined, so that the gp44/62.gp45'DNA.gp43 complex identified here may be only one intermediate in the formation of gp $45^{\mathrm{K}} \cdot \mathrm{DNA} \cdot \mathrm{gp} 43$.

\section{Different roles for ATP in formation of a holoenzyme in different organisms}

This mechanism of ATP utilization in bacteriophage T4 DNA polymerase holoenzyme assembly differs from that in both E. coli and eukaryotes. Although all three systems utilize ATP to form the holoenzyme, the timing and amount of ATP hydrolysis differs. Numerous biochemical studies of the loading mechanism in E. coli suggest that ATP binding is sufficient for opening the clamp $(\beta)$ and that hydrolysis of two or three molecules of ATP occurs after the clamp is loaded onto DNA. ${ }^{17,41,42}$ This differs from the bacteriophage T4 system in which ATP hydrolysis by the clamploader is required to open the clamp before interaction with DNA, although both systems hydrolyze ATP to close the clamp protein and recycle the clamp-loader. This as well as other differences between these two systems suggest that although the overall mechanism for holoenzyme assembly is similar, significant differences arise in the details of assembly. ${ }^{12}$ The clamps from the two systems have different oligomeric structures, and further evidence suggests that the overall stability of the clamps in solution and on DNA differ. ${ }^{43} \mathrm{Gp} 45$ is a partially open trimer is solution, ${ }^{33}$ while the $\beta$ clamp appears to be a closed dimer. ${ }^{41} \mathrm{Gp} 45$ on DNA dissociates with a rate of $\sim 0.1 \mathrm{~s}^{1}$ (step 13 in Figure 9(c)), while $\beta$ requires the assistance of $\delta$ to unload it off of DNA at a rate of $0.01 \mathrm{~s} \mathrm{~s}^{1.44}$

It is intriguing that the partially open gp45 clamp from bacteriophage T4 requires the hydrolysis of ATP by the clamp-loader for further opening to facilitate its loading onto DNA, while a closed $\beta$ clamp only requires ATP binding to the clamploader to derive a conformational change that opens the clamp. Both ATP $\gamma S$ and ADP will suffice to drive a segment of the reaction cycle in which the $\beta$ clamp protein of E. coli is apparently closed around the DNA substrate. ${ }^{19}$ Recent crystal structures of the E. coli clamp-loader and a part of the clamp-loader complexed with the $\beta$ clamp indirectly define the role of ATP in a proposed structural mechanism of holoenzyme formation in E. coli consistent with an ATP-binding mechanism that opens the clamp. ${ }^{7,8}$ In this mechanism, Jeruzalmi et al. suggest that hydrophobic residues within the subunit interface act to hold the $\beta$ clamp closed in solution but under strain. ${ }^{7}$ Binding of ATP to the clamp-loader causes a conformational change that acts to trap one $\beta$ monomer in an open conformation through a "spring-like" mechanism.

Although the eukaryotic holoenzyme assembly mechanism has not been as thoroughly examined as both the T4 and E. coli systems, current studies suggest that it may share similarities to both. Biochemical characterizations of the clamp-loader (RF-C) and clamp (PCNA) in yeast have shown that utilization of four molecules of ATP is necessary for effective loading of the holoenzyme, although hydrolysis is only needed for RF-C 
dissociation, similar to that of E. coli. ${ }^{21}$ Binding of ATP to RF-C proceeds sequentially through the initial binding of two molecules of ATP followed by conformational changes to allow the subsequent binding of two additional molecules of ATP. ${ }^{22}$ ATP $\gamma S$ can facilitate formation of both the RFC.PCNA and RF-C.PCNA.DNA complexes, ${ }^{45,46}$ suggesting that the hydrolysis of ATP is necessary only to release RF-C to from a PCNA.DNA complex. Low resolution structural studies of the holoenzyme assembly mechanism from humans show a slightly different picture. A large conformational change was observed by transmission electron microscopy and atomic force microscopy after hydrolysis of ATP by the RF-C.PCNA complex allowing both RF-C and PCNA to adopt an open conformation. ${ }^{11}$ This event was observed before addition of DNA and was not observed in the presence of ATP $\gamma \mathrm{S}$ similar to the T4 system. In this case, ATP hydrolysis appears necessary to open both the clamp and clamp-loader complex before loading onto DNA. It seems likely that subtle mechanistic differences in ATP utilization may occur even between eukaryotic organisms.

\section{Materials and Methods}

\section{Materials}

Oligonucleotide primers and substrates were prepared as previously described. ${ }^{32,33,47}$ The forked Bio62/ 34/36mer primer template forked DNA blocked with streptavidin, ${ }^{47}$ was used as the DNA substrate in all experiments. 7-Diethylamino-3-( $4^{\prime}$ maleimidylphenyl)-4methylcoumarin (CPM) and streptavidin were obtained from Molecular Probes (Eugene, OR). ATP and ATP $\gamma \mathrm{S}$ are from Roche Molecular Biochemicals (Indianapolis, IN). [ $\left.\gamma^{-32} \mathrm{P}\right]$ ATP was purchased form New England Nuclear (Boston, $\mathrm{MA})$. $4 \mathrm{FW}, \mathrm{MgCl}_{2}$, and $\mathrm{Mg}(\mathrm{OAc})_{2}$ are from Sigma (St. Louis, MO). All other materials were obtained from commercial sources and were of the highest available quality. The assay buffer used in all kinetic experiments consisted of $25 \mathrm{mM}$ Tris OAc ( $\mathrm{pH}$ 7.5), $150 \mathrm{mM} \mathrm{KOAc}$, and $10 \mathrm{mM} \mathrm{MgOAc}$.

\section{Protein purification and labeling}

Incorporation of $4 \mathrm{FW}$ into gp43 was performed according to a procedure described previously. ${ }^{48}$ pET26b-43[D219A] (43exo $)^{49}$ was transformed into a tryptophan auxotrophic E. coli cell strain containing the $\lambda \mathrm{DE} 3$ prophage (W3110DE3) and grown in medium with a limiting amount of tryptophan until they reached a stationary phase $\left(A_{600 \mathrm{~nm}} \sim 0.8\right) .{ }^{48,50,51}$ Cells were then cooled to room temperature and IPTG and $4 \mathrm{FW}$ were added to final concentrations of $0.25 \mathrm{mM}$ and $60 \mathrm{mg} \mathrm{l}^{1}$, respectively, to induce protein expression. Cells were incubated at $22{ }^{\circ} \mathrm{C}$ with shaking for an additional six hours. Purification of gp43-4FW and exonuclease deficient gp43 was performed similarly as described previously. ${ }^{49}$ The final protein concentration of gp43-4FW was determined by using an extinction coefficient corrected for the 4FW substitution: $103,229 \mathrm{M}^{1} \mathrm{~cm}^{1}$ at $265 \mathrm{~nm}$ rather than $125,900 \mathrm{M}^{1} \mathrm{~cm}^{1}$. 52 The ability of gp43-4FW to shutdown ATPase activity was verified as described earlier. ${ }^{33}$
The strand-displacement assay was conducted in a benchtop format to check the ability of gp43-4FW to displace a 36mer from the Bio62/34/36mer DNA substrate and extend the 34 mer to a 62 mer. $^{13,33}$ A double mutant of gp45 (W199F/V163C) ${ }^{33}$ and two triple mutants of gp45 containing no tryptophans and a single cysteine (W199F/V163C/W92F ${ }^{5}$ and W199F/S158C/W92F ${ }^{6}$ ) were prepared previously. Wild-type gp45, gp44/62, and exonuclease-deficient gp43 were purified as described earlier. ${ }^{49,53,54}$ Labeling of the gp45 mutants with CPM was performed as explained previously. ${ }^{33}$ The protein concentration of the CPM-labeled gp45 mutant was determined by a spectrometric Bradford protein assay (BioRad, Hercules, CA) using wild-type gp45 as a standard. Wild-type gp45 and gp44/62 protein concentrations were determined by UV spectroscopy at $280 \mathrm{~nm}$ using the appropriate extinction coefficients of 57,200 and 123,000 , respectively.

\section{Steady-state fluorescence spectroscopy}

Steady-state fluorescence experiments were performed on an ISA (Edison, NJ) FluoroMax-2 spectrofluorimeter thermostated to $25^{\circ} \mathrm{C}$. Fluorescence experiments were carried out as previously described. ${ }^{33}$ Excitation at $280 \mathrm{~nm}$ was used to quantify the amount of fluorescence at $330 \mathrm{~nm}$ for $43-4 \mathrm{FW}$ and compared to 43exo . Slit widths were $3 \mathrm{~nm}$ and emission was monitored in $1 \mathrm{~nm}$ increments with 0.5 second integration time. An average of four experiments was preformed to quantify the fluorescence at $330 \mathrm{~nm}$.

\section{Presteady-state stopped-flow fluorescence spectroscopy}

Stopped-flow fluorescence experiments were performed on an Applied Photophysics (Leatherhead, Surrey, UK) SX.18MV stopped-flow reaction analyzer in fluorescence mode at the constant temperature of $25^{\circ} \mathrm{C}$. The samples were excited at $290 \mathrm{~nm}$ or $390 \mathrm{~nm}$ as explained previously., ${ }^{5,6}$ A $420 \mathrm{~nm}$ cutoff filter was used to detect only CPM fluorescence. The excitation path length was $2 \mathrm{~mm}$. Single timebases were used, and 2000 data points collected. Excitation at $290 \mathrm{~nm}$ gave FRET between W92 and V163C-CPM of gp45, while excitation at $390 \mathrm{~nm}$ allowed for direct excitation of CPM without any contribution from tryptophan. The relative changes in fluorescence $\left(F_{\mathrm{AD}}^{290}\right)$ were corrected for changes in interprotein FRET and fluorophore environment $\left(F_{\mathrm{A}}^{290}\right.$ and $\left.F_{\mathrm{A}}^{390}\right)$ and converted to fluorescence intensities $\left(I_{\mathrm{AD}}\right.$ and $\left.I_{\mathrm{A}}\right)$ as described previously. ${ }^{5,6}$ The energy transfer between W92F and V163C-CPM is calculated using acceptor sensitization (equation (1)), and the distance between the donor and acceptor pair is calculated using the Förster relationship (equation (2)): ${ }^{55}$

$$
\begin{gathered}
E_{\mathrm{T}}=\left(\begin{array}{cc}
\frac{I_{\mathrm{AD}}}{I_{\mathrm{A}}} & 1
\end{array}\right)\left(\frac{\varepsilon_{\mathrm{A}}}{\varepsilon_{\mathrm{D}}}\right) \\
R=R_{\mathrm{O}} \sqrt[6]{\frac{1}{E_{\mathrm{T}}}} 1
\end{gathered}
$$

where $E_{\mathrm{T}}$ is the transfer efficiency of the FRET process, $I_{\mathrm{AD}}$ is the fluorescent intensity of the tryptophan donor in the presence of the CPM acceptor. $I_{\mathrm{A}}$ is the fluorescence intensity of the CPM acceptor in the absence of the tryptophan donor. $\varepsilon_{\mathrm{A}}$ and $\varepsilon_{\mathrm{D}}$ are the extinction coefficients of the CPM acceptor and the tryptophan donor at $290 \mathrm{~nm}$, and are equal to $3340 \mathrm{M}^{1} \mathrm{~cm}^{1}$ and 
$4100 \mathrm{M}^{1} \mathrm{~cm}^{1}$, respectively. ${ }^{33} R_{\mathrm{O}}$ is the Förster distance at which the transfer efficiency is $50 \%$, and $R$ is the distance between the donor and acceptor. $R_{\mathrm{O}}$ for gp45 W199F/V163C was calculated previously to be $31 \mathrm{~A}^{33}$ The energy transfer values $\left(E_{\mathrm{T}}\right)$ obtained experimentally are an average of the distances between the tryptophan donor and the CPM acceptor at all three subunit interfaces. We have assumed before that two of the subunit interfaces are closed $\left(E_{\mathrm{C}}\right)$ and do not change while the third interface is opened $\left(E_{\mathrm{O}}\right)$ during the holoenzyme formation process. ${ }^{5,6,33}$ Using this assumption, we can calculate the amount of $E_{\mathrm{O}}$ for the open interface from equation (3) using 0.95 for $E_{\mathrm{C}}$ determined previously: ${ }^{33}$

$$
E_{\mathrm{O}}=3 E_{\mathrm{T}} \quad 2 E_{\mathrm{C}}
$$

The interaction between the clamp and clamp-loader was also followed by stopped-flow spectroscopy. Interprotein FRET between the donor tryptophans in gp44/ 62 and the acceptor, CPM, on gp45-W199F/S158C/ W92F was monitored using the fluorescence parameters described above. Excitation at $290 \mathrm{~nm}$ followed changes in fluorescence, and thus distances, between gp45 and gp44/62 throughout holoenzyme assembly.

\section{ATP hydrolysis measurements}

All assays monitoring the hydrolysis of $\left[\gamma^{-}{ }^{32} \mathrm{P}\right] \mathrm{ATP}$ by gp44/62 were performed as previously described ${ }^{30}$ using a rapid-quench instrument. ${ }^{56} \mathrm{~A}$ typical presteadystate ATPase assay was performed by mixing a preincubated solution of $4 \mu \mathrm{M}$ gp44/62, $4 \mu \mathrm{M}$ gp45, and $10 \mathrm{mM}$ $\mathrm{Mg}^{2+}$ in the absence or presence of $4 \mu \mathrm{M}$ Bio62/34/ $36 \mathrm{mer}$ and $4 \mu \mathrm{M}$ streptavidin with $1 \mathrm{mM}$ ATP, $100 \mathrm{nM}$

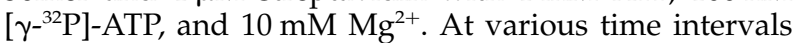
( $\Delta t=0.0160$ seconds), a $15 \mu$ l aliquot was quenched with the addition of either $15 \mu \mathrm{l}$ of $0.7 \mathrm{M}$ formic acid or $15 \mu \mathrm{l} 1 \mathrm{M}$ hydrochloric acid, then extracted with $100 \mu \mathrm{l}$ phenol/ $\mathrm{CHCl}_{3}$, and neutralized with $3 \mathrm{M} \mathrm{NaOH}$ in $1 \mathrm{M}$ Tris. After neutralization, the $\mathrm{pH}$ for each sample was 7.5. Aliquots quenched with formic acid were extracted with either chloroform or phenol/chloroform. A double-quench procedure was used in some cases and included an initial formic acid quench as described above followed by removal of $100 \mu \mathrm{l}$ of each sample quenched in $100 \mu \mathrm{l} \mathrm{HCl}$ and extracted and neutralized as above. The samples were analyzed using thin-layer chromatography to separate $\left[{ }^{32} \mathrm{P}_{\mathrm{i}}\right]$ from non-hydrolyzed $\left[\gamma^{32} \mathrm{P}\right]$ ATP using PEI-F cellulose TLC plates developed with $0.6 \mathrm{M}$ potassium phosphate buffer ( $\mathrm{pH}$ 3.5). TLC images were obtained with a Molecular Dynamics PhosphorImager. Product formation was quantified by measuring the ratio of $\left[{ }^{32} \mathrm{P}_{\mathrm{i}}\right]$ product and unhydrolyzed $\left[\gamma^{32} \mathrm{P}\right]$ ATP substrate. The ratios of product formation are corrected for substrate in the absence of enzyme (zero point). A radioactive impurity spot that did not migrate from the origin was corrected for as described in Supplemental Materials. Corrected ratios are then multiplied by the final concentration of ATP $(500 \mu \mathrm{M})$ used in each assay to yield the total concentration of ATP hydrolyzed. Controls were performed to measure the effect of $\mathrm{HCl} ; \mathrm{HCl}$ plus phenol $/ \mathrm{CHCl}_{3}$ prior to neutralization; $\mathrm{HCl}$ plus phenol/ $\mathrm{CHCl}_{3}$ followed by neutralization with $\mathrm{NaOH} /$ Tris on the hydrolysis of labeled ATP over a period of 30 minutes. The samples were analyzed as described above.

\section{Pulse-chase experiments}

Pulse-chase experiments were performed by mixing a preincubated solution of accessory proteins in the absence or presence of Bio62/34/36mer/streptavidin with ATP with the following modifications. In steady-state experiments, the reactants were mixed and allowed to react for five seconds prior to the addition of the cold chase (final concentration of $1 \mathrm{mM}$ ATP and $20 \mathrm{mM} \mathrm{Mg}^{2+}$ ). Aliquots of the reaction were then quenched at five second time intervals after the addition of cold chase using $\mathrm{HCl}$ as the chemical quench and processed as above. Transient pulsechase experiments were performed as described above with the exception that the cold chase $(1 \mathrm{mM}$ unlabelled ATP with $20 \mathrm{mM} \mathrm{Mg}^{2+}$ ) was added through the "quenching syringe" (third syringe). After a delay of seven seconds, the reaction was quenched through the manual addition of $100 \mu \mathrm{l} 1 \mathrm{M} \mathrm{HCl}$ or $0.7 \mathrm{M}$ formic acid. The $\mathrm{HCl}$ quenched samples were then extracted with $100 \mu \mathrm{l}$ of phenol/chloroform and then neutralized by the addition of approximately $35 \mu$ l of $3 \mathrm{M} \mathrm{NaOH} / 1 \mathrm{M}$ Tris.

\section{Data analysis}

Steady-state rates in ATP hydrolysis measured under pseudo-first order reaction conditions were fit to equation (4):

$$
y=m t+b
$$

where $m$ is the slope of the line, $b$ is the $y$-intercept, and $t$ is time. Data obtained from transient time-courses in ATP hydrolysis were fit to equation (5) which defines a burst in product formation followed by a steady-state rate:

$$
y=A \mathrm{e}^{k t}+B t+C
$$

where $A$ is the burst amplitude, $k$ is the first order rate constant, $B$ is the steady-state rate, $t$ is time, and $C$ is a defined constant. Stopped-flow traces and rapid-quench data were simulated using KinTekSim version $2.03^{57}$ using the mechanism shown in Figure 9(c). The simulated rates were optimized and individually varied to determine the importance of individual rates to the overall fit of the data. The rate constants shown in Figure 9(c) are an average of the simulated rates from previous reports ${ }^{5,6,30,32}$ and the simulated rates described here.

\section{Acknowledgements}

This research was supported in part by National Institutes of Health Grant GM13306-37 (S.J.B.) and American Cancer Society Grant IRG-91-022-06-IRG (A.J.B.). We would like to thank Peter von Hippel and Paola Pietroni for their review of our results and discussions on the bacteriophage T4 DNA polymerase holoenzyme assembly process.

\section{References}

1. Nossal, N. G. (1994). The bacteriophage T4 DNA replication fork. In Molecular Biology of Bacteriophage T4 (Karam, J. D., ed.), ASM Press, Washington, DC.

2. Benkovic, S. J., Valentine, A. M. \& Salinas, F. (2001). Replisome mediated DNA replication. Annu. Rev. Biochem. 70, 181208. 
3. Alley, S. C., Trakselis, M. A., Mayer, M. U., Ishmael, F. T., Jones, A. D. \& Benkovic, S. J. (2001). Building a replisome solution structure by elucidation of protein protein interactions in the bacteriophage $\mathrm{T} 4$ DNA polymerase holoenzyme. J. Biol. Chem. 276, 3934039349.

4. Kuriyan, J. \& O'Donnell, M. (1993). Sliding clamps of DNA polymerases. J. Mol. Biol. 234, 915925.

5. Alley, S. C., Abel-Santos, E. \& Benkovic, S. J. (2000). Tracking sliding clamp opening and closing during bacteriophage T4 DNA polymerase holoenzyme assembly. Biochemistry, 39, 30763090.

6. Trakselis, M. A., Alley, S. C., Abel-Santos, E. \& Benkovic, S. J. (2001). Creating a dynamic picture of the sliding clamp during T4 DNA polymerase holoenzyme assembly by using fluorescence resonance energy transfer. Proc. Natl Acad. Sci. USA, 98, 83688375

7. Jeruzalmi, D., Yurieva, O., Zhao, Y., Young, M., Stewart, J., Hingorani, M. et al. (2001). Mechanism of processivity clamp opening by the delta subunit wrench of the clamp loader complex of E. coli DNA polymerase III. Cell, 106, 417428.

8. Jeruzalmi, D., O’Donnell, M. \& Kuriyan, J. (2001). Crystal structure of the processivity clamp loader gamma complex of E. coli DNA polymerase III. Cell, 106, 429441.

9. Oyama, T., Ishino, Y., Cann, I. K., Ishino, S. \& Morikawa, K. (2001). Atomic structure of the clamp loader small subunit from Pyrococcus furiosus. Mol. Cell, 8, 455463.

10. Mayanagi, K., Miyata, T., Oyama, T., Ishino, Y. \& Morikawa, K. (2001). Three-dimensional electron microscopy of the clamp loader small subunit from Pyrococcus furiosus. J. Struct. Biol. 134, 3545.

11. Shiomi, Y., Usukura, J., Masamura, Y., Takeyasu, K., Nakayama, Y., Obuse, C. et al. (2000). ATP-dependent structural change of the eukaryotic clamp-loader protein, replication factor C. Proc. Natl Acad. Sci. USA, 97, 1412714132.

12. Trakselis, M. A. \& Benkovic, S. J. (2001). Intricacies in ATP-dependent clamp loading. Variations across replication systems. Structure, 9, 9991004.

13. Kaboord, B. F. \& Benkovic, S. J. (1996). Dual role of the $44 / 62$ protein as a matchmaker protein and DNA polymerase chaperone during assembly of the bacteriophage T4 holoenzyme complex. Biochemistry, 35, 10841092

14. McHenry, C. S. (1982). Purification and characterization of DNA polymerase III'. Identification of tau as a subunit of the DNA polymerase III holoenzyme. J. Biol. Chem. 257, 26572663.

15. Studwell-Vaughan, P. S. \& O'Donnell, M. (1991). Constitution of the twin polymerase of DNA polymerase III holoenzyme. J. Biol. Chem. 266, 1983319841.

16. Podust, V. N., Tiwari, N., Stephan, S. \& Fanning, E. (1998). Replication factor $C$ disengages from proliferating cell nuclear antigen (PCNA) upon sliding clamp formation, and PCNA itself tethers DNA polymerase delta to DNA. J. Biol. Chem. 273, 3199231999.

17. Bertram, J. G., Bloom, L. B., Hingorani, M. M., Beechem, J. M., O'Donnell, M. \& Goodman, M. F. (2000). Molecular mechanism and energetics of clamp assembly in Escherichia coli. The role of ATP hydrolysis when gamma complex loads beta on DNA. J. Biol. Chem. 275, 2841328420.
18. Hingorani, M. M., Bloom, L. B., Goodman, M. F. \& O'Donnell, M. (1999). Division of labor sequential ATP hydrolysis drives assembly of a DNA polymerase sliding clamp around DNA. EMBO J. 18, 51315144.

19. Turner, J., Hingorani, M. M., Kelman, Z. \& O'Donnell, M. (1999). The internal workings of a DNA polymerase clamp-loading machine. EMBO J. 18, 771783.

20. Leu, F. P. \& O'Donnell, M. (2001). Interplay of clamp loader subunits in opening the beta sliding clamp of Escherichia coli DNA polymerase III holoenzyme. J. Biol. Chem. 276, 4718547194.

21. Gomes, X. V. \& Burgers, P. M. (2001). ATP utilization by yeast replication factor C. I. ATP-mediated interaction with DNA and with proliferating cell nuclear antigen. J. Biol. Chem. 276, 3476834775.

22. Gomes, X. V., Schmidt, S. L. \& Burgers, P. M. (2001) ATP utilization by yeast replication factor C. II. Multiple stepwise ATP binding events are required to load proliferating cell nuclear antigen onto primed DNA. J. Biol. Chem. 276, 3477634783.

23. Schmidt, S. L., Gomes, X. V. \& Burgers, P. M. (2001). ATP utilization by yeast replication factor C. III. The ATP-binding domains of RFC2, RFC3, and RFC4 are essential for DNA recognition and clamp loading. J. Biol. Chem. 276, 3478434791.

24. Lee, S. H. \& Hurwitz, J. (1990). Mechanism of elongation of primed DNA by DNA polymerase delta, proliferating cell nuclear antigen, and activator 1. Proc. Natl Acad. Sci. USA, 87, 56725676.

25. Burgers, P. M. (1991). Saccharomyces cerevisiae replication factor C. II. Formation and activity of complexes with the proliferating cell nuclear antigen and with DNA polymerases delta and epsilon. J. Biol. Chem. 266, 2269822706.

26. Podust, L. M., Podust, V. N., Sogo, J. M. \& Hubscher, U. (1995). Mammalian DNA polymerase auxiliary proteins: analysis of replication factor C-catalyzed proliferating cell nuclear antigen loading onto circular double-stranded DNA. Mol. Cell Biol. 15, 30723081.

27. Waga, S. \& Stillman, B. (1998). Cyclin-dependent kinase inhibitor p21 modulates the DNA primer template recognition complex. Mol. Cell Biol. 18, 41774187.

28. Piperno, J. R. \& Alberts, B. M. (1978). An ATP stimulation of T4 DNA polymerase mediated via T4 gene $44 / 62$ and 45 proteins. The requirement for ATP hydrolysis. J. Biol. Chem. 253, 51745179.

29. Jarvis, T. C., Newport, J. W. \& von Hippel, P. H. (1991). Stimulation of the processivity of the DNA polymerase of bacteriophage T4 by the polymerase accessory proteins. The role of ATP hydrolysis. J. Biol. Chem. 266, 18301840.

30. Berdis, A. J. \& Benkovic, S. J. (1996). Role of adenosine 5'-triphosphate hydrolysis in the assembly of the bacteriophage T4 DNA replication holoenzyme complex. Biochemistry, 35, 92539265.

31. Young, M. C., Weitzel, S. E. \& von Hippel, P. H. (1996). The kinetic mechanism of formation of the bacteriophage T4 DNA polymerase sliding clamp. J. Mol. Biol. 264, 440452.

32. Sexton, D. J., Kaboord, B. F., Berdis, A. J., Carver, T. E. \& Benkovic, S. J. (1998). Dissecting the order of bacteriophage T4 DNA polymerase holoenzyme assembly. Biochemistry, 37, 77497756.

33. Alley, S. C., Shier, V. K., Abel-Santos, E., Sexton, D. J., Soumillion, P. \& Benkovic, S. J. (1999). Sliding clamp of the bacteriophage $\mathrm{T} 4$ polymerase has open and 
closed subunit interfaces in solution. Biochemistry, 38, 76967709.

34. Pietroni, P., Young, M. C., Latham, G. J. \& von Hippel, P. H. (2001). Dissection of the ATP-driven reaction cycle of the bacteriophage T4 DNA replication processivity clamp loading system. J. Mol. Biol. 309, 869891.

35. Berdis, A. J. \& Benkovic, S. J. (1997). Mechanism of bacteriophage T4 DNA holoenzyme assembly: The $44 / 62$ protein acts as a molecular motor. Biochemistry, 36, 27332743.

36. Sexton, D. J., Berdis, A. J. \& Benkovic, S. J. (1997). Assembly and disassembly of DNA polymerase holoenzyme. Curr. Opin. Chem. Biol. 1, 316322.

37. Pietroni, P., Young, M. C., Latham, G. J. \& von Hippel, P. H. (1997). Structural analyses of gp45 sliding clamp interactions during assembly of the bacteriophage T4 DNA polymerase holoenzyme. I. Conformational changes within the gp44/62-gp45ATP complex during clamp loading. J. Biol. Chem. 272, 3166631676.

38. Latham, G. J., Bacheller, D. J., Pietroni, P. \& von Hippel, P. H. (1997). Structural analyses of gp45 sliding clamp interactions during assembly of the bacteriophage T4 DNA polymerase holoenzyme. III. The gp43 DNA polymerase binds to the same face of the sliding clamp as the clamp loader. J. Biol. Chem. 272, 3168531692

39. Latham, G. J., Bacheller, D. J., Pietroni, P. \& von Hippel, P. H. (1997). Structural analyses of gp45 sliding clamp interactions during assembly of the bacteriophage T4 DNA polymerase holoenzyme. II. The gp44/62 clamp loader interacts with a single defined face of the sliding clamp ring. J. Biol. Chem. 272, 3167731684

40. Alley, S. C., Ishmael, F. T., Jones, A. D. \& Benkovic, S. J. (2000). Mapping protein protein interactions in the bacteriophage T4 DNA polymerase holoenzyme using a novel trifunctional photocrosslinking and affinity reagent. J. Am. Chem. Soc. 122, 61266127.

41. Hingorani, M. M. \& O'Donnell, M. (1998). ATP binding to the Escherichia coli clamp loader powers opening of the ring-shaped clamp of DNA polymerase III holoenzyme. J. Biol. Chem. 273, 2455024563.

42. Bertram, J. G., Bloom, L. B., Turner, J., O'Donnell, M., Beechem, J. M. \& Goodman, M. F. (1998). Pre-steady state analysis of the assembly of wild type and mutant circular clamps of Escherichia coli DNA polymerase III onto DNA. J. Biol. Chem. 273, 2456424574.

43. Yao, N., Turner, J., Kelman, Z., Stukenberg, P. T., Dean, F., Shechter, D. et al. (1996). Clamp loading, unloading and intrinsic stability of the PCNA, beta and gp45 sliding clamps of human, E. coli and T4 replicases. Genes Cells, 1, 101113.

44. Leu, F. P., Hingorani, M. M., Turner, J. \& O'Donnell, M. (2000). The delta subunit of DNA polymerase III holoenzyme serves as a sliding clamp unloader in Escherichia coli. J. Biol. Chem. 275, 3460934618.

45. Tsurimoto, T. \& Stillman, B. (1991). Replication factors required for SV40 DNA replication in vitro. I. DNA structure-specific recognition of a primer template junction by eukaryotic DNA polymerases and their accessory proteins. J. Biol. Chem. 266, 19501960.

46. Gerik, K. J., Gary, S. L. \& Burgers, P. M. (1997). Overproduction and affinity purification of Saccharomyces cerevisiae replication factor C. J. Biol. Chem. 272, 12561262
47. Kaboord, B. F. \& Benkovic, S. J. (1993). Rapid assembly of the bacteriophage T4 core replication complex on a linear primer/template construct. Proc. Natl Acad. Sci. USA, 90, 1088110885.

48. Soumillion, P., Sexton, D. J. \& Benkovic, S. J. (1998). Clamp subunit dissociation dictates bacteriophage T4 DNA polymerase holoenzyme disassembly. Biochemistry, 37, 18191827.

49. Frey, M. W., Nossal, N. G., Capson, T. L. \& Benkovic, S. J. (1993). Construction and characterization of a bacteriophage T4 DNA polymerase deficient in $3^{\prime} \rightarrow 5^{\prime}$ exonuclease activity. Proc. Natl Acad. Sci. USA, 90, 25792583.

50. Hoeltzli, S. D. \& Frieden, C. (1994). 19F NMR spectroscopy of [6-19F]tryptophan-labeled Escherichia coli dihydrofolate reductase: equilibrium folding and ligand binding studies. Biochemistry, 33, 55025509.

51. Soumillion, P., Jespers, L., Vervoort, J. \& Fastrez, J. (1995). Biosynthetic incorporation of 7-azatryptophan into the phage lambda lysozyme: estimation of tryptophan accessibility, effect on enzymatic activity and protein stability. Protein Eng. 8, 451456.

52. Bronskill, P. M. \& Wong, J. T. (1988). Suppression of fluorescence of tryptophan residues in proteins by replacement with 4-fluorotryptophan. Biochem. J. 249, 305308.

53. Nossal, N. G. (1979). DNA replication with bacteriophage T4 proteins. Purification of the proteins encoded by T4 genes 41, 45, 44, and 62 using a complementation assay. J. Biol. Chem. 254, 60266031.

54. Rush, J., Lin, T. C., Quinones, M., Spicer, E. K., Douglas, I., Williams, K. R. \& Konigsberg, W. H. (1989). The 44P subunit of the T4 DNA polymerase accessory protein complex catalyzes ATP hydrolysis. J. Biol. Chem. 264, 1094310953.

55. Selvin, P. R. (1995). Fluorescence resonance energy transfer. Methods Enzymol. 246, 300334.

56. Johnson, K. A. (1995). Rapid quench kinetic analysis of polymerases, adenosinetriphosphatases, and enzyme intermediates. Methods Enzymol. 249, 3861.

57. Barshop, B. A., Wrenn, R. F. \& Frieden, C. (1983). Analysis of numerical methods for computer simulation of kinetic processes: development of KINSIM a flexible, portable system. Anal. Biochem. 130, 134145.

58. Sexton, D. J., Carver, T. E., Berdis, A. J. \& Benkovic, S. J. (1996). Protein protein and protein DNA interactions at the bacteriophage T4 DNA replication fork. Characterization of a fluorescently labeled DNA polymerase sliding clamp. J. Biol. Chem. 271, 2804528051. 